\title{
The Holocene vegetation cover of Britain and Ireland: overcoming problems of scale and discerning patterns of openness
}

\section{Ralph M. Fyfe ${ }^{\mathrm{a}, *}$, Claire Twiddle ${ }^{\mathrm{b}}$, Shinya Sugita ${ }^{\mathrm{c}}$, Marie-José Gaillard ${ }^{\mathrm{d}}$, Philip Barratt ${ }^{\mathrm{e}}$, Christopher J. Caseldine ${ }^{\text {f }}$, John Dodson ${ }^{g}$, Kevin J. Edwards ${ }^{\text {b }}$, Michelle Farrell ${ }^{\text {h }}$, Cynthia Froyd $^{\mathrm{i}}$, Michael J. Grant ${ }^{\mathrm{j}, \mathrm{k}}$, Elizabeth Huckerby ${ }^{\mathrm{l}}$, James B. Innes ${ }^{\mathrm{m}}$, Helen Shaw ${ }^{\mathrm{n}}$, Martyn Waller ${ }^{\mathrm{k}}$}

a School of Geography, Earth and Environmental Sciences, Plymouth University, Plymouth PL4 8AA, UK

${ }^{\mathrm{b}}$ Department of Geography \& Environment, School of Geosciences, University of Aberdeen, Elphinstone Road, Aberdeen AB24 $3 U F$, UK

${ }^{c}$ Institute of Ecology, Tallinn University, Uus-Sadama 5, 10120 Tallinn, Estonia

${ }^{\mathrm{d}}$ School of Natural Sciences, Linnaeus University, Barlastgatan 11, SE-39182 Kalmar, Sweden

e Department of Archaeology and Palaeoecology, School of Geography, Queen's University of Belfast, 42 Fitzwilliam Street, Belfast BT9 6AX, UK

${ }^{\mathrm{f}}$ College of Life and Environmental Sciences, University of Exeter, Treliever Road, Penryn TR10 9EZ, UK

${ }^{g}$ Institute for Environmental Research, ANSTO, New Illawarra Road, Lucas Heights, NSW 2234, Australia

${ }^{\mathrm{h}}$ Department of Geography, Environment and Earth Sciences, University of Hull, Cottingham Road, Hull HU6 7RX, UK

i Department of Geography, Swansea University, Swansea SA2 8PP, UK

${ }^{\mathrm{j}}$ Wessex Archaeology, Portway House, Old Sarum Park, Salisbury, Wilts SP4 6EB, UK

${ }^{\mathrm{k}}$ School of Geography, Geology and Environment, Kingston University, Penrhyn Road, Kingston upon Thames KT1 2EE, UK

${ }^{1}$ Oxford Archaeology North, Moor Lane Mills, Moor Lane, Lancaster LA1 1GF, UK

${ }^{m}$ Department of Geography, Durham University, South Road, Durham DH1 3LE, UK

${ }^{\mathrm{n}}$ Lancaster Environment Centre, Lancaster University, Lancaster LA1 4YQ UK

\section{A $\quad$ R $\quad$ T I I C C L E}

\section{Article history:}

Received 5 February 2013

Received in revised form

14 May 2013

Accepted 15 May 2013

Available online 19 June 2013

\section{Keywords:}

Pollen analysis

British Isles

Vegetation

Landscape openness

REVEALS

Holocene

\begin{abstract}
A B S T R A C T
The vegetation of Europe has undergone substantial changes during the course of the Holocene epoch, resulting from range expansion of plants following climate amelioration, competition between taxa and disturbance through anthropogenic activities. Much of the detail of this pattern is understood from decades of pollen analytical work across Europe, and this understanding has been used to address questions relating to vegetation-climate feedback, biogeography and human impact. Recent advances in modelling the relationship between pollen and vegetation now make it possible to transform pollen proportions into estimates of vegetation cover at both regional and local spatial scales, using the Landscape Reconstruction Algorithm (LRA), i.e. the REVEALS (Regional Estimates of VEgetation Abundance from Large Sites) and the LOVE (LOcal VEgetation) models. This paper presents the compilation and analysis of 73 pollen stratigraphies from the British Isles, to assess the application of the LRA and describe the pattern of landscape/woodland openness (i.e. the cover of low herb and bushy vegetation) through the Holocene. The results show that multiple small sites can be used as an effective replacement for a single large site for the reconstruction of regional vegetation cover. The REVEALS vegetation estimates imply that the British Isles had a greater degree of landscape/woodland openness at the regional scale than areas on the European mainland. There is considerable spatial bias in the British Isles dataset towards wetland areas and uplands, which may explain higher estimates of landscape openness compared with Europe. Where multiple estimates of regional vegetation are available from within the same region inter-regional differences are greater than intra-regional differences, supporting the use of the REVEALS model to the estimation of regional vegetation from pollen data.
\end{abstract}

(c) 2013 Elsevier Ltd. All rights reserved.

\footnotetext{
* Corresponding author. Tel.: +44 1752 585929; fax: +44 1752233054.

E-mail address: ralph.fyfe@plymouth.ac.uk (R.M. Fyfe).
}

\section{Introduction}

The vegetation of Europe has undergone substantial changes during the course of the Holocene epoch. This has resulted from range expansion of plants following climate amelioration and 
competition between taxa during the earlier Holocene (e.g. Birks, 1989) and disturbance through anthropogenic activities during the later Holocene. These changes have culminated in the presentday cultural landscapes. Through the development and widespread application of pollen-analytical techniques, much is understood concerning the processes that have driven regional-scale vegetation change, both through examination of individual pollen stratigraphies and synthesis of large numbers of pollen datasets (e.g. Huntley and Birks, 1983; Giesecke et al., 2011). Pollen stratigraphies are biased, however, owing to differential pollen production and dispersal mechanisms, meaning that the pollen percentages used within such studies do not always relate well to the abundance of plant and vegetation types in the past. For example, the relationship between the arboreal/non-arboreal pollen ratio and vegetation openness is non-linear (Sugita et al., 1999; Hellman et al., 2009a), making the ratio an inadequate proxy for landscape/woodland openness. McLauchlan et al. (2007) define landscape openness as the proportional cover of forest and grassland vegetation; here the term landscape/woodland openness is taken as the cover of low herb and bushy vegetation, which can be measured at various spatial scales.

There remains a strong need for systematic data on regional changes in past land/vegetation cover across a broad spectrum of consumers of pollen data, including natural and cultural heritage managers, palaeo-climatologists and archaeologists. Archaeologists frequently draw on pollen-analytical data to provide the context for their sites, to assess resource availability and to determine the scale of human landscape transformation (Evans, 2003). Archaeological applications require fine-grained reconstructions of vegetation for most questions (e.g. visibility analysis; Cummings and Whittle, 2003), but regionalised vegetation cover can provide an important overview of landscape character and human impact (e.g. Kreuz, 2008; Woodbridge et al., 2013). Better estimates of vegetation cover can also provide improved understanding of land cover-climate feedbacks at the regional and global scale and a means to evaluate other regional/global reconstructions of past anthropogenic land cover (e.g. Kaplan et al., 2009; Goldewijk et al., 2010) and simulations of past vegetation using dynamic vegetation models (Gaillard et al., 2010).

A variety of approaches have been developed to interpret pollen data in terms of vegetation change, including indicator species approaches (Behre, 1986), modern analogue and multivariate methods (e.g. Gaillard et al., 1994), and assignment of pollen taxa to plant functional types to reconstruct biomes (Prentice et al., 1996) or land cover classes (Fyfe et al., 2010). However, none of these methods are capable of quantifying vegetation cover (a measure of the relative proportion of different plant taxa). During the course of the past decade, advances in the application of the extended Rvalue models and mechanistic pollen dispersal-deposition models developed in the 1980s (Parsons and Prentice, 1981; Prentice and Parsons, 1983; Prentice, 1985) have led to the development of model-based reconstructions of land cover - first with the POLLSCAPE programmes (Sugita, 1994) and subsequently with the establishment of the Landscape Reconstruction Algorithm (LRA: Sugita, 2007a, b). The LRA, a framework for quantification of local vegetation cover (described below), represents an important advance in quantification of past regional and local land cover through the application of the REVEALS (Regional Estimates of Vegetation Abundance from Large Sites) and LOVE (Local Vegetation Estimates) models on pollen records from large and small sites (lakes or bogs), drawing on estimates of the relative pollen productivity and fall speed of pollen $(\mathrm{m} / \mathrm{s})$ of key taxa to transform pollen proportions into estimates of vegetation cover. The REVEALS model has been successfully tested against modern and recent vegetation cover using pollen from lake sediments in Europe
(Hellman et al., 2008a; Nielsen and Odgaard, 2010; Soepboer et al., 2010) and in northern America (Michigan and Wisconsin; Sugita et al., 2010). The entire LRA approach, implying the application of both the REVEALS and LOVE models, has been tested and evaluated thus far in northern America (Sugita et al., 2010), Denmark (Nielsen and Odgaard, 2010; Overballe-Petersen et al., 2012), and southern Sweden (Fredh, 2012; Cui et al., 2013).

The aim of this paper is to present regionalised former vegetation cover of the British Isles based on the application of the REVEALS model on a large number of sites. The British Isles are of particular interest, as unlike other parts of Europe, it has been suggested that its landscapes may have been substantially cleared of woodland by the historic period. Rackham (1986) argues that by 2500 cal BP the British Isles had only $50 \%$ woodland cover, which was reduced to $15 \%$ by 900 cal BP and reached levels of $5 \%$ at the start of the twentieth century. We therefore seek to determine whether the British Isles had different levels of landscape/woodland openness from mainland Europe earlier in the Holocene. This study is part of the LANDCLIM (LAND cover - CLIMate interactions in NW Europe during the Holocene) project, the major objective of which is to quantify human-induced changes in regional vegetation/land-cover in northwestern Europe during the Holocene with the purpose to assess the possible effects on the climate of two historical processes (compared with a baseline of presentday land cover): (i) climate-driven changes in vegetation, and (ii) human-induced changes in land cover (Gaillard et al., 2010). The full methodological protocol used for the REVEALS application in LANDCLIM is described in Mazier et al. (2012), and the REVEALS reconstructions for the whole study region are presented in Trondman et al. (submitted).

Previous studies from mainland Europe have successfully applied the REVEALS model using pollen records from large lakes (Sugita et al., 2008 (southern Sweden); Soepboer et al., 2010 (Swiss Plateau)), and from multiple large and small sites (lakes and bogs) (Nielsen et al., 2012) (Denmark and northern Germany). The latter study is also part of the LANDCLIM project and use the same methodological protocol. The particular aims of the British Isles study are (i) to assess the application of the REVEALS model to regions for which data are not readily available from the ideal site types (large lakes); (ii) to assess how open the landscape/woodlands of the British Isles was during the Holocene at the regional scale; and (iii) to assess the degree of regional vegetation heterogeneity through time. The approach taken is to produce regional vegetation cover for groups of taxa in 500 year time slices from 10,200 cal BP to the present day for Britain and Ireland.

\section{The Landscape Reconstruction Algorithm}

This paper attempts to estimate past regional vegetation composition based on pollen count data from the British Isles using the first step of the LRA. The LRA is a framework for the estimation of vegetation abundance within the relevant source area of sedimentary basins based on pollen count data (Sugita, 2007a, b). The LRA has two steps: estimation of regional vegetation using the REVEALS (Regional Estimates of VEgetation Abundance from Large Sites) model (Sugita, 2007a), and estimation of vegetation from within the relevant source area of pollen (RSAP) of target, smaller sites using the LOVE (LOcal Vegetation Estimates) model (Sugita, 2007b). Full details of the LRA can be found in Sugita (2007a, b) and Sugita et al. (2010). The REVEALS model is a generalised form of the R-value model (Davis, 1963) which estimates regional vegetation abundance of a taxon at a given depositional basin using (i) pollen count data from the site; (ii) an estimate of the relative pollen productivity of the taxon (PPE); (iii) an estimate of the fall 
speed of pollen (FSP; m/s); (iv) the radius of the depositional basin; (v) an estimate of the maximum extent of the region from which pollen is derived; and (vi) a taxon-specific pollen dispersaldeposition function based either on Prentice (1985) for bogs or Sugita (1994) for lakes. The LOVE model requires in addition (vi) an estimate of the regional vegetation abundance (REVEALS estimates); (vii) pollen counts from target small basins; (viii) an estimate of the RSAP of the target basin; and (ix) the radius of the target basin. The RSAP is defined as the distance beyond which background pollen is consistent at similarly sized sites; in modern pollen/vegetation comparisons, it is best described as the distance beyond which the correlation between pollen and vegetation abundance does not improve (Sugita, 2007b).

The LRA has a series of assumptions that have been described in detail (Sugita, 2007a, b; Sugita et al., 2010) and the implications of these have been discussed elsewhere (Nielsen, 2004; Bunting and Middleton, 2005; Gaillard et al., 2008; Hellman et al., 2008a,b; Sugita et al., 2010). Critical parameters within the LRA are PPEs and FSP for the taxa of interest from each site, and the estimate of the RSAP for target basins. PPEs are derived empirically by describing the relationship between vegetation and pollen abundance in the modern landscape (see e.g. Broström et al., 2008). The FSP is a measure of the rate at which pollen grains settle in the atmosphere, and are derived from the literature or calculated according to Stokes' Law (see Broström et al., 2004, 2008).

A key assumption for the application of the REVEALS and LOVE models is that PPEs are constant in both space and time. The RSAP of multiple sites within a homogenous region (in terms of vegetation type) can be calculated for the present-day or hypothetical vegetation compositions (a forward modelling approach for which both vegetation and pollen data are required), and it is recognised that the RSAP is controlled by a series of factors, the spatial distribution of plants around the site being the most significant (Bunting et al., 2004; Broström et al., 2005; Hellman et al., 2009a ,b). The RSAP for past situations is estimated by the LOVE model using an inverse approach based on the premise that there cannot be either more than $100 \%$ or less than $0 \%$ vegetation within the source area of pollen (Sugita, 2007b). The LOVE model is parameterised to increase the estimate of source area until this situation is reached, a distance described as the necessary source area of pollen (NSAP) at individual sites; RSAP is then defined as the largest of the necessary source area among the sites studied (Sugita et al., 2010). The REVEALS model assumes that pollen records from large sites ( $>50-100 \mathrm{ha})$ reflect the regional vegetation $(>50-100 \mathrm{~km})$ and do not differ significantly among those sites; therefore the RSAP is sufficiently large and not determined by any statistical methods.

The REVEALS model is being applied to all readily available pollen data across northwest Europe as part of the LANDCLIM project (Gaillard et al., 2010), including data from the pan-European pollen database (EPD: Fyfe et al., 2009), regional and national databases (e.g. PALYCZ for the Czech Republic: Kuneŝ et al., 2009) and data contributed by individual researchers. The LANDCLIM project is producing regional vegetation estimates for a $1^{\circ} \times 1^{\circ}$ grid, transformed into 10 plant functional types (PFTs) for use in datamodel output comparisons (see Gaillard et al., 2010 for detailed rationale behind the methodological protocol). Inclusion of all available pollen data in a rigid gridded approach may result in poor estimates of regional vegetation, particularly when the spatial distribution of sites is sparse and estimates are made on isolated small sites which are inherently local in character. The approach used here is to test whether groups of small sites can be used to estimate regional vegetation (following Sugita et al., 2010), and to produce regional vegetation estimates for the British Isles for those areas where suitable data are available.

\section{The UK and Irish pollen dataset}

The British Isles have a long tradition of pollen-analytical investigations dating back to the 1920s (Godwin, 1975), and the number of sites from which pollen has been counted must easily exceed 1000 . There is no complete audit of the number of sites from which pollen has been counted. Various regional reviews have provided insights into the number and distribution of datasets. For example, Tipping (1994) reviewed data from 239 pollen sequences in Scotland (excluding archaeological and coastal sites); a metadataonly database of pollen sequences in Ireland (IPOL) lists 475 sequences (Stefanini and Mitchell, 2011). The depth of British and Irish pollen work has been drawn on in a variety of review papers, which also reveals disparities in the quality of datasets available (which is in part determined by the research question). Tipping (1994) used only 73 sequences in his analysis of woodland cover in Scotland; Birks (1989) used 135 sequences in his review of the establishment of British and Irish tree cover; Grant et al. (2011) used 115 sequences in a review of the Tilia decline in lowland Britain (largely England); and Dark (2006) used 75 sequences based on chronological criteria for an analysis of Bronze Age vegetation change. These syntheses all used published diagrams for their analyses.

The key distinction between these studies and the work presented here is that the LRA requires raw pollen count data from dated sequences, and cannot use estimates of values of taxa taken from percentage-based diagrams. This limits the number of sites that can be used to those for which pollen count data are readily available. Count data were initially collated from the EPD, and further contributions were sought from individual analysts. Sites were selected using a number of key criteria for inclusion, established within the LANDCLIM project (Mazier et al., 2012): (i) sufficient chronological control, with at least three radiocarbon dates or equivalent age markers; (ii) raw pollen count data; (iii) sufficient metadata (e.g. site radius) required for the LRA; (iv) precise geolocational data for the site. Pollen data from archaeological sites with complex taphonomies were avoided. The complete database comprises 114 dated pollen records (Fig. 1), including coastal sequences which are frequently omitted in other syntheses, although only a subset of these are used for complete analysis (Section 6.1).

There is considerable spatial bias in the dataset which reflects three factors. The first is the geology of the British Isles: there are few deposits suitable for pollen analysis within large parts of central and southern England. The second is regional interests of individual analysts who have developed in-depth projects in particular landscapes areas, resulting in dense clusters of sites. The third factor concerns wider issues surrounding the archiving of data (see Fyfe et al., 2009), including loss of metadata, retirement of analysts, non-archiving of datasets by analysts (or data being in 'legacy' formats or only available in paper form), a lack of awareness of the possibilities to contribute or archive datasets in central locations such as the EPD, or the unwillingness to contribute material to communal databases.

\section{Application of LRA in non-ideal situations}

The database of pollen data for the British Isles that has been compiled is not ideal for the application of the LRA. The approach sensu stricto (Sugita, 2007a, b) requires pollen count data from large sites for best estimates of vegetation abundance, i.e. estimates with as small error estimates as possible. Published REVEALS estimates of past vegetation have used large lakes (Sugita et al., 2008; Soepboer et al., 2010; Nielsen et al., 2012; Cui et al., 2013). There are few locations in the British Isles outside Scotland where count data from large lakes are readily available. This is not a problem unique to the British Isles (Mazier et al., 2012), 


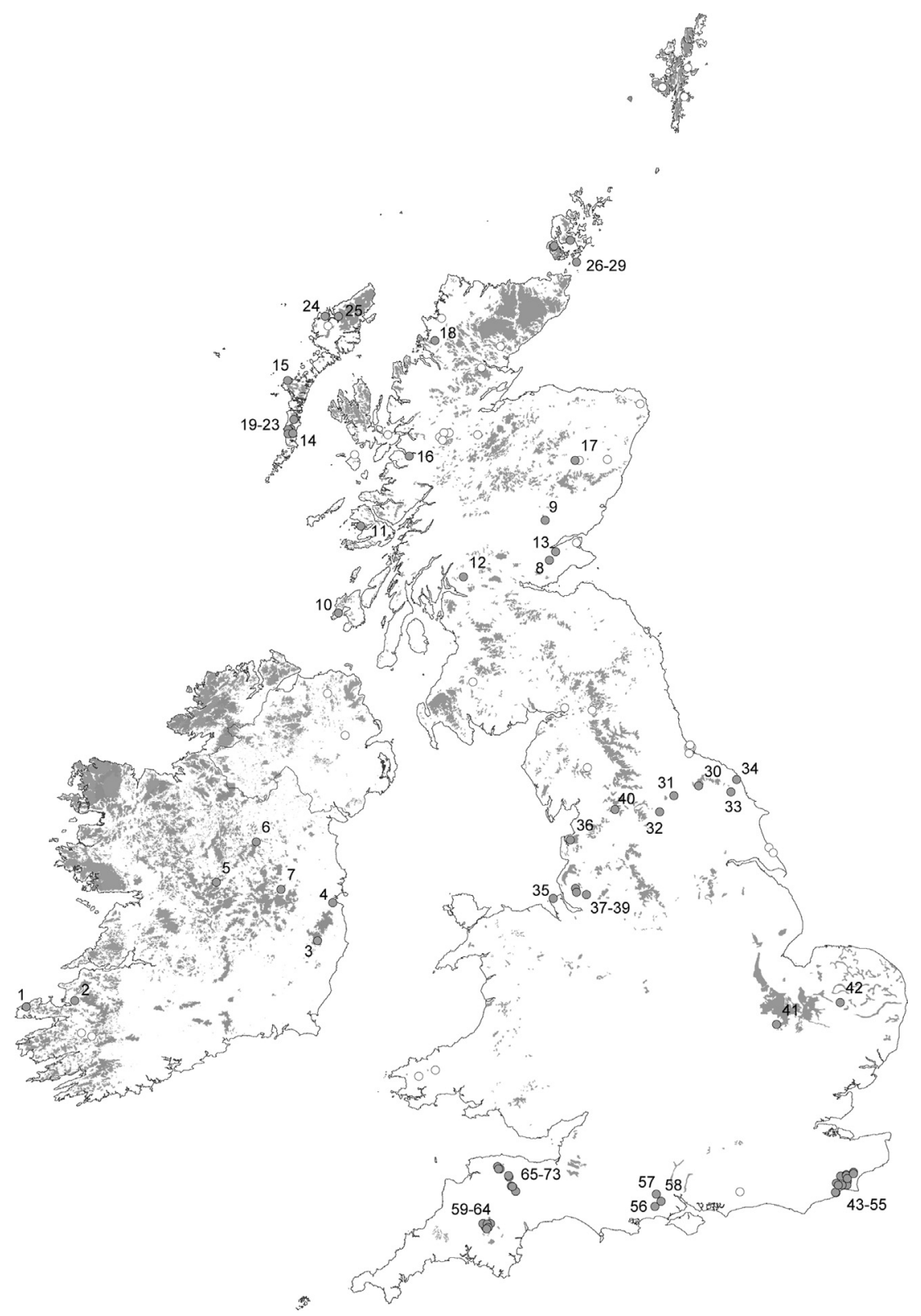

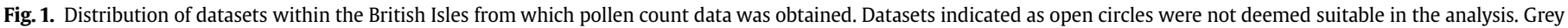
shading indicates the current and recent extent of peat (Connolly, no date; JNCC, 2011). Peaty soils are excluded from this map.

and data paucity may reflect a real absence of work from large lakes, the absence of large lakes in the landscape or the unavailability of pollen count data from large lakes that does exist. Much recent pollen-based work has deliberately sampled smaller basins in an attempt to match the spatial scale of representation to either the archaeological landscape or the level of the vegetation unit of interest (e.g. Hannon et al., 2008; Griesman and Gaillard, 2009; Fyfe, 2012). One of the assumptions of the REVEALS model is that no pollen is derived from plants growing on the basin (Sugita, 2007a). This has implications when using bogs, and in particular large bogs, where on-site vegetation may comprise a significant proportion of the pollen sum. Mazier et al. (2012) compared REVEALS results from bogs and lakes of various sizes in the same region and found no systematic differences in the ranking of PFT estimates using the Spearman rank-order correlation test. Analysis of the impact of site type on the REVEALS estimates is in progress using the entire dataset of the LANDCLIM project (Trondman et al., in prep.). To resolve the problem of unavailability of count data from large lakes, multiple small sites can be used. Simulations have shown that pollen assemblages from lakes $>48$ ha (mean radius $>$ ca $390 \mathrm{~m}$ ) can be used reliably for regional vegetation estimates even when the vegetation and land-cover are patchy (Sugita, 2007a). It was also shown by model simulations that REVEALS can be used with pollen records from a number of smaller-sized sites, although error estimates will usually be large (Sugita, 2007a). Sugita et al. (2010) found that REVEALS estimates using pollen data from 21 small forest hollows (Northwestern Wisconsin) adequately described regional vegetation. In their discussion, Sugita et al. (2010) suggested that the number of sites required depended on the complexity of regional vegetation (a consequence of its spatial structure and vegetation composition and diversity) and the size of the 'small' basins. As the basins increase in size, and as the number of small sites increases, the between-site variation should decrease (Sugita, 2007a). 
The Northwestern Wisconsin situation of high numbers of sites with readily available data is unlikely to be common within the European or global palynological record, and the British situation is more typical, where perhaps data from 2 to 10 dated sequences may be available within a region. In this instance, generating regional vegetation estimates may be more challenging. The first section of this paper tests the application of a small number of sites for generating both regional and local vegetation estimates using the LRA. This is done by comparing the results of the LRA using first a large lake and second a set of small lakes for generation of the regional vegetation cover.

\section{Testing the value of a network of small sites as indicators of regional vegetation cover}

The selection of the area for testing the LRA with regionalised vegetation from a large lake and from small lakes is determined by the distribution of sites in the British Isles. The only area that is suitable from the database is the Western Isles of Scotland. The sites include a large lake (Loch Olabhat) and six smaller ones (Table 1). The LRA requires each site to be organised into age-equivalence classes (time windows). This allows direct comparison of records from separate sites that is otherwise not possible. A new age-depth model was produced for each site using CLAM (Blaauw, 2010). A range of methods for deriving age-depth models was tested, with the best fit for each sequence used to assign each pollen count a calibrated age BP. Pollen counts from each site were aggregated into 500 -year bins to produce a single count for each time window. Only anemophilous taxa for which PPEs are available (25 taxa: Broström et al., 2008; Mazier et al., 2012) were used (Table 2); percentage values for each site for each time window were calculated on the sum of the 25 taxa used. This typically represented over $90 \%$ of the original count.

The two-step LRA was run twice to return two estimates for the local vegetation abundance within the RSAP of the six small sites. Estimates were made for fourteen 500-year time windows between 3700 and $4200 \mathrm{cal} \mathrm{BP}$ and $9700-10200 \mathrm{cal} \mathrm{BP}$. The first run used pollen counts from the large lake to estimate regional vegetation abundance (LRA step 1: REVEALS submodel); the second run used pollen counts from the small lakes to estimate regional vegetation abundance. For the second run, six separate sets of regional vegetation estimates were calculated, each excluding the small site for which local vegetation was to be estimated to avoid autocorrelation. The PPEs used (Table 2) were taken from Broström et al. (2008) and are the same as those employed by Gaillard et al. (2010), Nielsen et al. (2012) and Mazier et al. (2012). This ensures comparability with vegetation estimates from other studies. Once two sets of regional vegetation estimates were available for each target site, the second step of the LRA (LOVE submodel) was run for each site, twice. This produced two estimates of local vegetation abundance around each target site, using either regional vegetation derived from the large lake or regional vegetation derived from the group of small lakes.

Results of the LRA runs are shown in Fig. 2. For each taxon, estimates of local vegetation abundance for all time windows for all sites are presented in simple bi-plots with standard errors. Samples in Fig. 2 are not a priori independent, as there is likely to be some temporal autocorrelation. In general there is good correspondence between local vegetation estimates produced using regional vegetation estimated from a large site, and from a group of smaller sites. This is in agreement with Mazier et al. (2012). Standard errors are generally larger when a group of small sites is used to estimate regional vegetation, supporting the findings of Sugita et al. (2010). Overall, these results demonstrate that it is possible to substitute groups of small sites for large lakes to produce estimates of regional vegetation within the LRA, even when the number of available sites is low (Hellman et al., 2008b).

\section{Past regional vegetation of the British Isles: results}

\subsection{Regionalised vegetation cover: methodological approach}

Only 73 datasets from the compiled pollen data from the British Isles (Section 3) were used to generate regionalised vegetation estimates (Fig. 1, Table 1). The approach used here has been to use large lakes, or groups of medium and small sites. Sites that were both small and lay outside a clear geographical grouping, or where there was a mix of small lakes and mires (which are not easily combined within the REVEALS analyses), were excluded. Small sites are those $<50$ ha in size (Sugita, 2007b; Mazier et al., 2012); the small sites used by Sugita et al. (2010) were $<1$ ha in size. The records were filtered to retain only those taxa for which PPEs are available. Age-depth models were calculated as before (using CLAM: Blaauw, 2010) to aggregate individual samples from each site into 500 year time windows between 10,200 and 700 cal BP and three shorter time windows for the recent period (700-350, 350-100 and 100-0 cal BP). Each 'binned' sample was an aggregate of multiple counts (typically 3-10), resulting in large pollen sums. Sequences were grouped into coherent regional datasets, based on their broad geographical distribution (Fig. 1; Table 1). The REVEALS model (Sugita, 2007a) was run on each regional grouping. For data visualisation purposes, each taxon was assigned into one of six classes: coniferous trees, deciduous trees, shrubs, heath, grasses, other herbaceous taxa (Table 2). The class heath includes only Calluna vulgaris. This presents a potential problem, as changes in the proportions of $C$. vulgaris may reflect development and expansion of bogs at the regional level, or may be part of other upland vegetation types. The heath class should therefore be used as an expression of the amount of heath or bog at the regional level. There is also a potential bias, as many of the sites used in the analysis are bogs. Mazier et al. (2012) found no systematic bias between REVEALS-based regional vegetation based on bogs or lakes in the Czech Republic pollen record, implying that the records from the smaller and large bogs in their study were representative of the regional vegetation cover.

\subsection{Estimates of regional vegetation}

\subsubsection{Vegetation cover of the Scottish islands}

The regional vegetation cover of Scotland is based on data from nine large lakes, and four groups of sites (Fig. 3). The estimates of regional vegetation for the Western Isles show low levels of woodland/shrub cover at 10,200 cal BP, which is less than $10 \%$ by 4200 cal BP in all cases. The character of the decline between the four different estimates varies: at Frobost (bog) woodland/shrub values are very low by 8200 cal BP, whilst the grouped Southern Hebrides sites indicate a steady decline. At Loch Olabhat (large lake) a distinct decline in woodland/shrubs is evident around 6200 cal BP; the (two) grouped Northern Hebrides sites again suggest gradual decline. The open ground is characterised by a mix of heath and grassland, with heath gradually increasing, appearing to replace deciduous woodland/ shrubs. The grouped results from Orkney show similar patterns of landscape/woodland openness to the western Isles, with almost no woodland/shrub cover from $4700 \mathrm{cal} \mathrm{BP}$, and very low values prior to this time (rarely greater than 10\%). The open ground taxa show a clear decrease in heath between 6200 and 4200 cal BP, which gradually returns to become the dominant ground cover by 2700 cal BP. In contrast to the more northern island groups, the south-western islands indicate a different 
Table 1

Sites included within REVEALS analysis. Site number refers to numbers of Fig. 1.

\begin{tabular}{|c|c|c|c|c|c|c|c|c|}
\hline Site no. & Site name & Latitude & Longitude & Elevation $(\mathrm{m})$ & Type & Site radius $(\mathrm{m})$ & Regional grouping & Reference \\
\hline 1 & Ballinloghig Lough $^{\mathrm{a}}$ & 52.2 & -10.35 & 108 & Lake & 75 & & Barnosky, 1988 \\
\hline 2 & Lough Camclaun & 52.3 & -9.7 & 76 & Lake & 800 & & Dodson, 1990 \\
\hline 3 & Arts Lough ${ }^{\mathrm{a}}$ & 52.973 & -6.424 & 591 & Lake & 100 & & Bradshaw and McGee, 1988 \\
\hline 4 & Glendalough & 53.3 & -6.25 & 59 & Lake & 175 & & J. Maldonado unpublished \\
\hline 5 & Mongan Bog & 53.4 & -7.9 & 90 & Bog & 691 & Irish bogs & Parkes and Mitchell, 2000 \\
\hline 6 & Derragh Bog & 53.766 & -7.383 & 71 & Bog & 250 & Irish bogs & Brown et al., 2005 \\
\hline 7 & Carbury Bog & 53.383 & -6.983 & 90 & Bog & 800 & Irish bogs & van Geel and Middeldorp, 1988 \\
\hline 8 & West Lomond & 56.246 & -3.287 & 293 & Lake & 50 & CE Scotland & Edwards and Whittington, 1997 \\
\hline 9 & Rae Loch & 56.584 & -3.37 & 119 & Lake & 65 & CE Scotland & Edwards and Whittington, 1997 \\
\hline 10 & Loch a'Bhogaidh & 55.732 & -6.421 & 61 & Lake & 400 & & Edwards and Berridge, 1994 \\
\hline 11 & A'Chrannag & 56.473 & -6.171 & 1 & Lake & 300 & & Sugden, 1999 \\
\hline 12 & Loch Lomond $^{\mathrm{a}}$ & 56.086 & -4.583 & 66 & Lake & 1000 & & Dickson et al., 1978 \\
\hline 13 & Black Loch & 56.32 & -3.196 & 118 & Lake & 200 & & Whittington et al., 1991a \\
\hline 14 & Frobost & 57.203 & -7.379 & 42 & Bog & 200 & & Mulder, 1999 \\
\hline 15 & Loch Olabhat ${ }^{\mathrm{b}}$ & 57.65 & -7.455 & 39 & Lake & 290 & & Mulder, 1999 \\
\hline 16 & Loch Maree ${ }^{a}$ & 57.083 & -5.483 & 319 & Lake & 1800 & & Birks, 1972 \\
\hline 17 & Loch Davan & 57.092 & -2.925 & 196 & Lake & 370 & & Edwards, 1978 \\
\hline 18 & Loch Sionascaig $^{\mathrm{a}}$ & 58.061 & -5.175 & 105 & Lake & 1390 & & Pennington et al., 1972 \\
\hline 19 & North Locheynort ${ }^{\mathrm{b}}$ & 57.243 & -7.341 & 31 & Lake & 70 & S Hebrides & Edwards, 1996 \\
\hline 20 & Reineval $^{\mathrm{b}}$ & 57.233 & -7.366 & 56 & Lake & 59 & S Hebrides & Edwards, 1996 \\
\hline 21 & Loch A'Chabhain ${ }^{\mathrm{b}}$ & 57.238 & -7.384 & 22 & Lake & 100 & S Hebrides & Mulder, 1999 \\
\hline 22 & Loch Airigh na h-Achlais ${ }^{\mathrm{b}}$ & 57.327 & -7.305 & 15 & Lake & 120 & S Hebrides & Mulder, 1999 \\
\hline 23 & Loch airigh na h-Aon Oidhche ${ }^{\mathrm{b}}$ & 57.209 & -7.308 & 93 & Lake & 125 & S Hebrides & Edwards et al., 1995 \\
\hline 24 & Loch Bharabhat & 58.21 & -6.942 & 1 & Lake & 80 & N Hebrides & Lomax, 1997 \\
\hline 25 & Loch na Beinne Bige & 58.218 & -6.73 & 52 & Lake & 140 & N Hebrides & Lomax, 1997 \\
\hline 26 & Keith's Peat Bank & 58.883 & -3.326 & 148 & Bog & 750 & Orkney & Blackford et al., 1996 \\
\hline 27 & Hobbister & 58.941 & -3.051 & 5 & Bog & 250 & Orkney & Farrell, 2009 \\
\hline 28 & Whaness Burn & 58.889 & -3.311 & 83 & Bog & 250 & Orkney & Farrell, 2009 \\
\hline 29 & Blows Moss & 58.758 & -2.943 & 13 & Bog & 1250 & Orkney & Farrell et al., 2013 \\
\hline 30 & Bonfield Gill Head & 54.354 & -1.081 & 318 & Bog & 50 & NE England & Innes unpublished \\
\hline 31 & Newby Wiske & 54.272 & -1.434 & 42 & Bog & 50 & NE England & Innes in press \\
\hline 32 & Sharow mires & 54.138 & -1.643 & 157 & Bog & 200 & NE England & Innes in press \\
\hline 33 & Seavy Slack & 54.3 & -0.617 & 153 & Bog & 15 & NE England & Innes unpublished \\
\hline 34 & Stoup Beck & 54.4 & -0.527 & 159 & Bog & 15 & NE England & Innes unpublished \\
\hline 35 & Park Road Meols & 53.403 & -3.147 & 4 & Bog & 25 & NW England & Cowell and Innes, 1994 \\
\hline 36 & Fenton Cottage & 53.9 & -2.916 & 1 & Bog & 100 & NW England & Wells et al., 1997 \\
\hline 37 & Simonswood Moss B & 53.49 & -2.837 & 54 & Bog & 100 & NW England & Cowell and Innes, 1994 \\
\hline 38 & Parr Moss & 53.439 & -2.681 & 14 & Bog & 100 & NW England & Cowell and Innes, 1994 \\
\hline 39 & Knowsley Park & 53.458 & -2.822 & 75 & Bog & 100 & NW England & Cowell and Innes, 1994 \\
\hline 40 & Winmarleigh Moss & 54.159 & -2.286 & 382 & Bog & 430 & NW England & Wells et al., 1997 \\
\hline 41 & Willingham Mere ${ }^{a}$ & 52.333 & -0.051 & 25 & Lake & 320 & & Waller et al., 1994 \\
\hline 42 & Hockham Mere ${ }^{\mathrm{a}}$ & 52.5 & 0.833 & 44 & Lake & 420 & & Bennett, 1983 \\
\hline 43 & Pannel Bridge $^{a}$ & 50.9 & 0.683 & 1 & Bog & 100 & SE England & Waller, 1993 \\
\hline 44 & Brookland & 50.996 & 0.835 & 12 & Bog & 10,000 & SE England & Wells et al., 1997 \\
\hline 45 & Little Cheyne Court & 50.962 & 0.832 & 3 & Bog & 10,000 & SE England & Wells et al., 1997 \\
\hline 46 & East Guldeford & 50.964 & 0.766 & 2 & Bog & 5000 & SE England & Waller and Schofield, 2007 \\
\hline 47 & Pannel Farm & 50.905 & 0.677 & 4 & Bog & 50 & SE England & Waller and Schofield, 2007 \\
\hline 48 & Peasmarsh & 50.981 & 0.692 & 7 & Bog & 900 & SE England & Waller and Schofield, 2007 \\
\hline 49 & Lea Farm & 50.967 & 0.717 & 3 & Bog & 52 & SE England & Long et al., 2007 \\
\hline 50 & Chapel Bank & 51.041 & 0.752 & 9 & Bog & 1000 & SE England & Long et al., 2007 \\
\hline 51 & Horsemarsh Sewer & 51.051 & 0.828 & 15 & Bog & 10,000 & SE England & Waller et al., 1999 \\
\hline 52 & The Dowels & 51.044 & 0.828 & 15 & Bog & 10,000 & SE England & Waller et al., 1999 \\
\hline 53 & Hope Farm & 51.019 & 0.839 & 16 & Bog & 10,000 & SE England & Waller et al., 1999 \\
\hline 54 & Romney Marsh 7 & 51.068 & 0.925 & 39 & Bog & 10,000 & SE England & Long et al., 1998a,b \\
\hline 55 & Romney Marsh 18 & 51.058 & 0.924 & 25 & Bog & 10,000 & SE England & Long et al., 1998a,b \\
\hline 56 & Church Moor & 50.861 & -1.649 & 60 & Bog & 150 & New Forest & Grant et al., 2009a, b \\
\hline 57 & Barrow Moor & 50.921 & -1.711 & 76 & Bog & 100 & New Forest & Grant et al., 2009a, b \\
\hline 58 & Cranes Moor & 50.817 & -1.731 & 58 & Bog & 350 & New Forest & Grant et al., 2009a, b \\
\hline 59 & Stonetor Brook & 50.656 & -3.91 & 409 & Bog & 15 & Dartmoor & Fyfe et al., 2008 \\
\hline 60 & Cut Hill & 50.628 & -3.982 & 513 & Bog & 100 & Dartmoor & Fyfe and Woodbridge 2012 \\
\hline 61 & Broad Amicombe & 50.654 & -4.013 & 536 & Bog & 50 & Dartmoor & Maguire 1983 \\
\hline 62 & Hangingstone Hill & 50.654 & -3.957 & 480 & Bog & 100 & Dartmoor & Fyfe and Woodbridge, 2012 \\
\hline 63 & Winneys Down & 50.623 & -3.943 & 469 & Bog & 200 & Dartmoor & Fyfe and Woodbridge, 2012 \\
\hline 64 & Broad Down & 50.612 & -3.962 & 485 & Bog & 150 & Dartmoor & Fyfe and Woodbridge, 2012 \\
\hline 65 & Hares Down & 50.978 & -3.644 & 226 & Bog & 10 & N Devon & Fyfe et al., 2004 \\
\hline 66 & Lobbs Bog & 50.97 & -3.624 & 279 & Bog & 15 & N Devon & Fyfe et al., 2004 \\
\hline 67 & North Coombe & 50.932 & -3.59 & 192 & Bog & 15 & N Devon & Fyfe et al., 2004 \\
\hline 68 & Moles Chamber & 51.139 & -3.834 & 411 & Bog & 15 & N Devon & Fyfe, 2012 \\
\hline 69 & Comerslade & 51.12 & -3.804 & 459 & Bog & 50 & N Devon & Fyfe, 2012 \\
\hline 70 & Windmill Rough & 50.975 & -3.633 & 266 & Bog & 10 & N Devon & Fyfe et al., 2004 \\
\hline 71 & Gourte Mires & 51.054 & -3.678 & 288 & Bog & 20 & N Devon & Fyfe et al., 2003 \\
\hline 72 & Long Breach & 51.066 & -3.687 & 311 & Bog & 20 & N Devon & Fyfe et al., 2003 \\
\hline 73 & N. Twitchen Springs & 51.117 & -3.825 & 441 & Bog & 15 & N Devon & Fyfe, 2012 \\
\hline
\end{tabular}

a indicates data taken from the EPD.

b indicates sites used to test the value of a network of small sites as indicators of regional vegetation cover. 
Table 2

Details of pollen taxa used within the REVEALS and LRA analysis.

\begin{tabular}{llll}
\hline Taxon & PPE & $\begin{array}{l}\text { Fall speed } \\
\left(\mathrm{ms}^{-1}\right)\end{array}$ & Grouping \\
\hline Abies & 6.88 & 0.12 & Coniferous trees \\
Alnus & 9.07 & 0.021 & Deciduous trees \\
Artemisia & 3.48 & 0.025 & Other herbaceous \\
Betula & 3.09 & 0.024 & Deciduous trees \\
Calluna vulgaris & 0.82 & 0.038 & Heath \\
Carpinus & 3.55 & 0.042 & Deciduous trees \\
Cerealia-t & 1.85 & 0.06 & Other herbaceous \\
Corylus & 1.99 & 0.025 & Shrubs \\
Cyperaceae & 0.87 & 0.035 & Other herbaceous \\
Fagus & 2.35 & 0.057 & Deciduous trees \\
Filipendula & 2.81 & 0.006 & Other herbaceous \\
Fraxinus & 1.03 & 0.022 & Deciduous trees \\
Poaceae & 1 & 0.035 & Grasses \\
Juniperus & 2.07 & 0.016 & Shrubs \\
Picea & 2.62 & 0.056 & Coniferous trees \\
Pinus & 6.38 & 0.031 & Coniferous trees \\
Plantago lanceolata & 1.04 & 0.029 & Other herbaceous \\
Plantago media & 1.27 & 0.024 & Other herbaceous \\
Plantago montana & 0.74 & 0.03 & Other herbaceous \\
Quercus & 5.83 & 0.035 & Deciduous trees \\
Rumex acetosa-t & 2.14 & 0.018 & Other herbaceous \\
Salix & 1.22 & 0.022 & Shrubs \\
Secale-t & 3.02 & 0.06 & Other herbaceous \\
Tilia & 0.8 & 0.032 & Deciduous trees \\
Ulmus & 1.27 & 0.032 & Deciduous trees \\
\hline & & & \\
\hline
\end{tabular}

regional vegetation cover throughout the Holocene, with much greater woodland/shrub cover. Loch a'Bhogaidh (large lake) records consistent levels of woodland/shrub cover (65-75\%) between 10,200 and 4200 cal BP, with an abrupt halving of woodland/shrub cover at 4200 cal BP (to 35\%). This site had infilled and become a mire by this time. Woodland is replaced by heath and grassland. Woodland/shrub cover then gradually declines, with an increase in herbaceous taxa.

\subsubsection{Vegetation cover of mainland Scotland}

The REVEALS vegetation cover estimates from mainland Scotland show a clear pattern of expansion of woodland in the early Holocene, reaching its maximum cover by 6700 cal BP (Fig. 3). The vegetation cover is rarely stable, but is characterised in the main by continual change. The period with the greatest degree of stability (i.e. least change between time windows) is the last 1500 years. There is a clear contrast in woodland types between the southeast (Black Loch and the Central-Eastern lakes) and other parts of Scotland. This is marked by the presence/absence of coniferous woodland in the estimates of vegetation cover. This is broadly consistent with reconstructions of the extent of the former Caledonian pine woods (Bennett, 1995). Woodland generally begins to decline at 6700-6200 cal BP from its maximum coverage. The pattern of woodland decline is regionally variable, for example at Black Loch woodland declines abruptly between the 4700-4200 and 4200-3700 cal BP time slices; both Loch Davan and Loch Maree have steady declines in woodland cover, although from different initial levels (with higher overall estimates from Loch Davan). This may relate to smoothing of regional patterns when sites are grouped together. There is clear evidence for significant heath on the western Scottish coast since at least $6200 \mathrm{cal} \mathrm{BP}$ at Loch Sionascaig and 9200 cal BP at Loch Maree. At Loch Maree, heath progressively expands throughout the Holocene, and largely replaces woodland and shrub cover after $7700 \mathrm{cal} \mathrm{BP}$. The centraleastern sites also record extensive heath $(>20 \%)$ by 8700 cal BP, although this is not the case at the eastern sites of Black Loch and Loch Davan.

\subsubsection{Vegetation cover of England}

Six sets of grouped records from peat sequences and two large lakes provide the basis for estimates of the regional vegetation cover of England (Fig. 4). The spatial bias in the record has already been discussed; there remain large gaps in available data for regional reconstructions. There is no overall single pattern of vegetation cover for England (e.g. of woodland cover), and patterns of vegetation cover change show considerable differences through time. 'Pre-disturbance' woodland cover (pre-Neolithic, c. 6000 cal BP) varies from over 95\% at Hockham Mere, to less than $40 \%$ in the Northwest (although this is from a single time slice). Reductions in woodland extent are gradual in all sequences, with no evidence for abrupt declines in woodland cover at this temporal resolution. With the exception of Hockham Mere and the New Forest, the estimates suggest very open landscapes (>80\% open cover) by 2200 cal BP.

\subsubsection{Vegetation cover of Ireland}

The REVEALS vegetation estimates are based on data from four large lakes and a combined set of large mires from the central part of Ireland (Fig. 5). The combined bog records cover only the past 4200 years. There is a contrast between the estimates of vegetation cover from the eastern and western lakes. In the east maximum woodland/shrub cover (>90\%) occurs at the start of the record (10,200-9200 cal BP) and subsequently declines as grass cover increases. Coniferous woodland cover is low, and is greatly reduced by the $8700-8200$ cal BP time slice. The two western records have a different pattern of change, with increasing cover of deciduous and coniferous woodland, albeit at different levels between the two lakes (40\% until the 6700-6200 cal BP time slice at Lough Camclaun and $85 \%$ at Ballinloghig Lough). Both the western lakes record increasing heath cover through the records, a pattern that is picked up in the midlands bogs at $4200 \mathrm{cal} \mathrm{BP}$ (with heather cover at $>20 \%$ in all three regional estimates).

\section{Discussion}

\subsection{Past landscape/woodland openness in Britain and Ireland}

The results of the transformation of pollen data to estimates of vegetation cover for the British Isles show a significantly higher level of landscape/woodland openness than that suggested by pollen percentage data. It is difficult to demonstrate this for regional vegetation estimates based on groups of sites, but it is clear when comparing pollen proportions to vegetation estimates from large lakes (Fig. 6). The under-representation of open ground taxa in pollen records of the northern hemisphere has been recognised for many years (e.g. Andersen, 1970; Broström et al., 2008) but the degree to which landscape/woodland openness was underrepresented by NAP percentages was only demonstrated by Sugita et al. (1999). The first application of REVEALS on European Holocene pollen records is that of Sugita et al. (2008) (see also Gaillard et al., 2010) using pollen data from large lakes in southern Sweden. It showed that the REVEALS estimates of open vegetation cover were twice to five time as high as the NAP percentage values. Trends apparent within pollen percentage data (e.g. increase in shrubs from 10 to 20\%, 5000-4000 cal BP, Loch Maree: Fig. 6) are not always replicated within the reconstructed vegetation cover, as previously demonstrated through simulation experiments (Fyfe, 2006). This emphasises the non-linear relationship between pollen percentage data and vegetation cover (sensu Sugita et al., 1999; Hellman et al., 2009a). The under-representation of landscape/ woodland openness is also clear in the other published REVEALS estimates from elsewhere in Europe, including the contemporary landscape in Sweden (Hellman et al., 2008a), and the past regional 


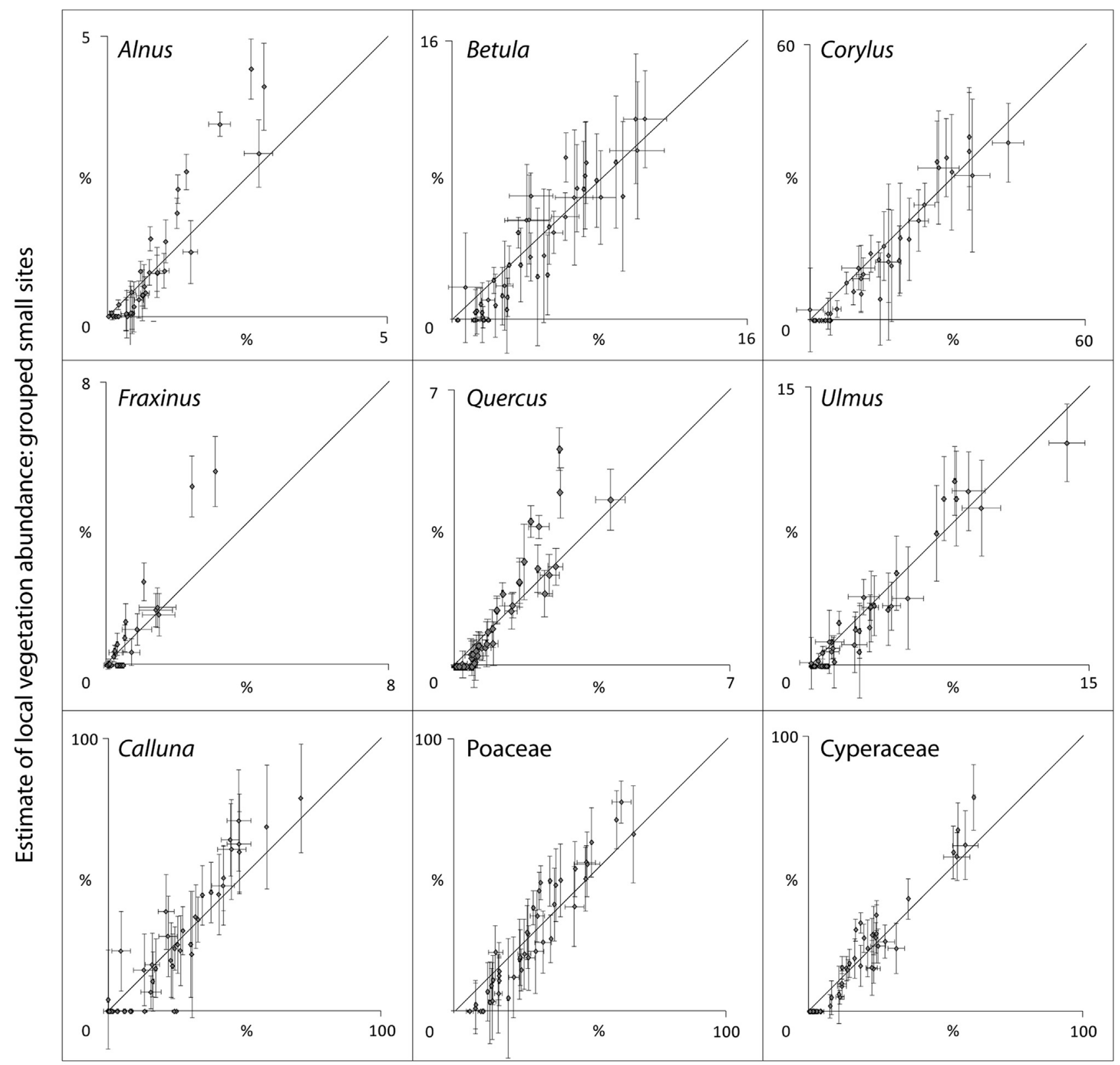

Estimate of local vegetation abundance: large site

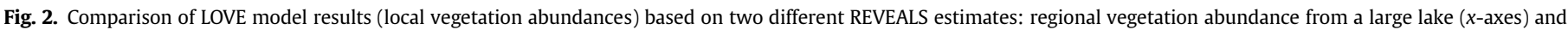
regional vegetation abundance from grouped small sites ( $y$-axes). Axis lengths are different between plots.

vegetation on the Swiss Plateau (Soepboer et al., 2010) and Denmark and northern Germany (Nielsen et al., 2012). Estimates of past landscape/woodland openness by Nielsen et al. (2012) at around $6700 \mathrm{cal} \mathrm{BP}$ are between 10 and 20 percent, but reach up to 40 percent on the western Danish coast. Soepboer et al. (2010) estimate landscape/woodland openness on the Swiss Plateau to be 41 percent at around $2000 \mathrm{cal} \mathrm{BP}$. Landscape/woodland openness of the British landscape is therefore generally greater than the estimates that are available from elsewhere in Europe, suggesting that the higher levels of openness argued by Rackham (1986) for the UK existed in the earlier Holocene as well as more recent times.

The under-representation of landscape/woodland openness from pollen data has significant implications. First, understanding of land cover-climate interactions require estimates of vegetation cover to assess the role of biophysical and biogeochemical feedbacks resulting from land cover change (Gaillard et al., 2010). Underestimation of openness will result in poor approximations of the role that these feedback mechanisms play (Kaplan et al., 2010). Second, palaeoecology, including pollen analysis, has been used to underpin debates within nature conservation in recent years, including design of ecological reserves applying the so-called Vera hypothesis (Vera, 2000; Mitchell, 2005). The vegetation estimates presented here suggest more openness in the regional vegetation of Britain that pollen percentage data, but cannot at this stage be used to test the Vera hypothesis. The results describe first-order approximations of landscape/woodland openness at the regional scale, not the openness of woodland at the local scale: REVEALS results do not describe vegetation structure. Openness at the 


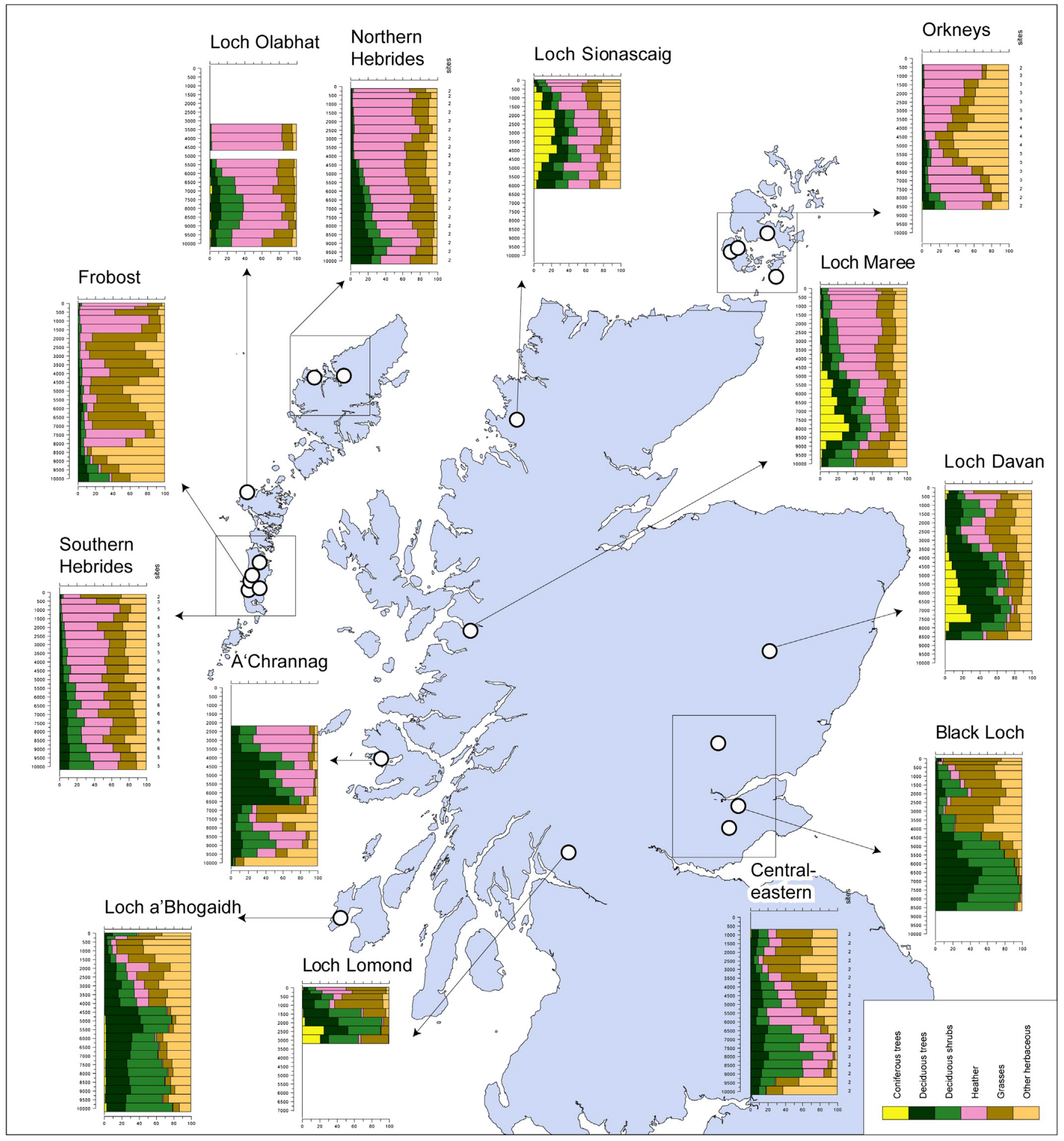

Fig. 3. Estimated Holocene regional vegetation cover types for Scotland derived from the REVEALS model.

regional scale includes the development of heath and bog during the Holocene (see Section 7.2), as well as anthropogenic changes and woodland openness. Palaeoecological data have already been used to indicate intra-regional differences in openness (e.g. Brown, 1997; Skinner and Brown, 1999; Bradshaw et al., 2003; Fyfe, 2007). Application of the LOVE model to estimate vegetation abundance within the RSAP of basins is necessary to address spatial differences in vegetation patterns within regions. It may be possible in future studies to use changes in the RSAP to assess vegetation structure, as vegetation heterogeneity is known to be an important control on the RSAP (Bunting et al., 2004).

\subsection{Spatial and temporal heterogeneity of vegetation}

The estimates of vegetation cover, and in particular landscape/ woodland openness, vary considerably between the different regions presented here (Figs. 3-5). Variability in land-cover (as suggested by pollen data) at the local scale has been recognised 


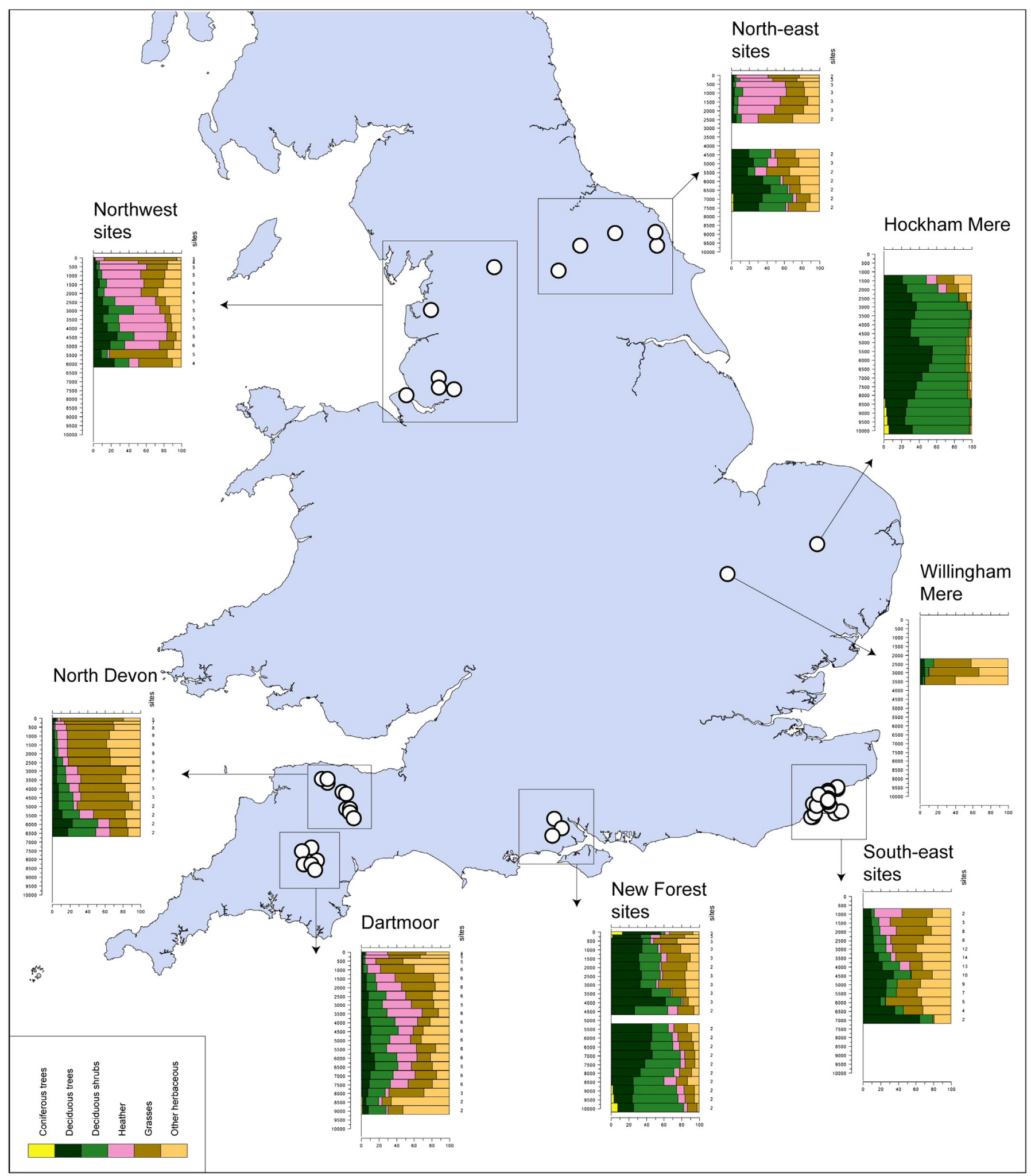

Fig. 4. Estimated Holocene regional vegetation cover types for England derived from the REVEALS model.

before, and has underpinned stand-scale vegetation reconstruction (e.g. Davis et al., 1998; Lindbladh et al., 2000; Schauffler and Jacobson, 2002; Fyfe et al., 2003; Davies and Tipping, 2004). The degree to which regions differ in their regional vegetation composition was assessed using principal components analysis
(PCA) undertaken in Canoco4.52 (ter Braak, 1987). PCA was chosen as the most appropriate ordination method as initial data analysis using detrended correspondence analysis showed a short gradient on the first axis (Lepŝ and Ŝmilauer, 2003). The PCA allows comparison of (proportion-based) regional vegetation estimates from 


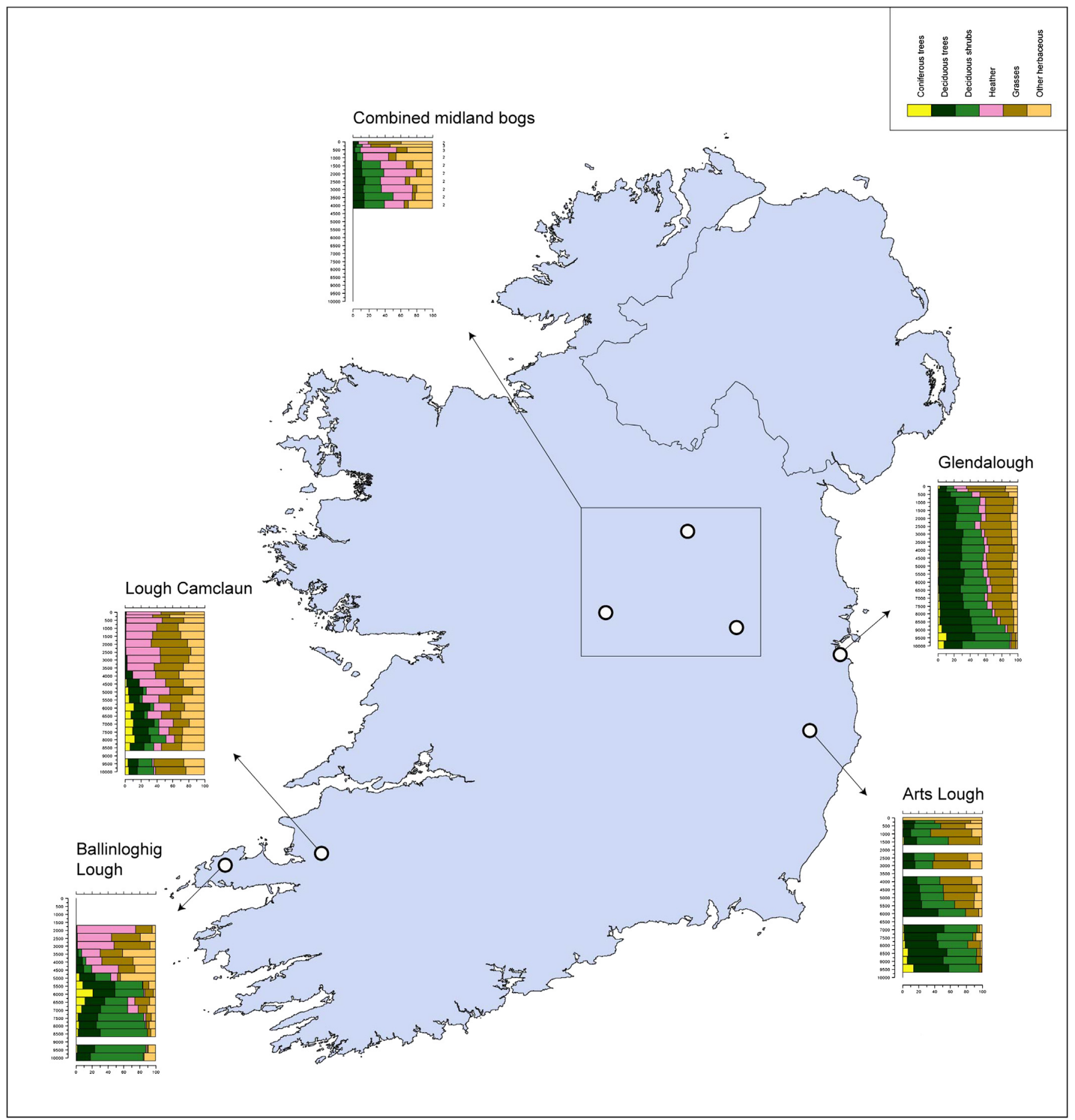

Fig. 5. Estimated Holocene regional vegetation cover types for Ireland derived from the REVEALS model.

within the region, where more than one group of sites is available, and between regions. PCA species scores are shown in Fig. 7. Only the Scottish sequences have sufficient regional estimates to make both intra- and inter-regional comparison possible. For the purposes of comparison, four broad landscape units are recognised: eastern mainland Scotland; western mainland Scotland; southwest Scottish islands; and northwest Scottish islands (Fig. 8). For clarity of visualisation each landscape unit is plotted separately. There is a broad separation of the four regions within the PCA, for example the vegetation trajectories from the southwestern and northwestern Scottish islands lie in different parts of the ordination space. This supports the reconstruction of a regional vegetation (i.e. vegetation out to $100 \mathrm{~km}$ from a basin) using the REVEALS approach. There are some differences between sites within the same region (e.g. Fig. 8A). This may reflect some bias within the sites that are used for the reconstruction, and in particular the aggregation of non-ideal sites to derive regional vegetation estimates, and the character of the more local geography around these sites, including differences between uplands and lowlands, in particular in regions that have highly variable topography which may influence a range of edaphic and climatic conditions. 

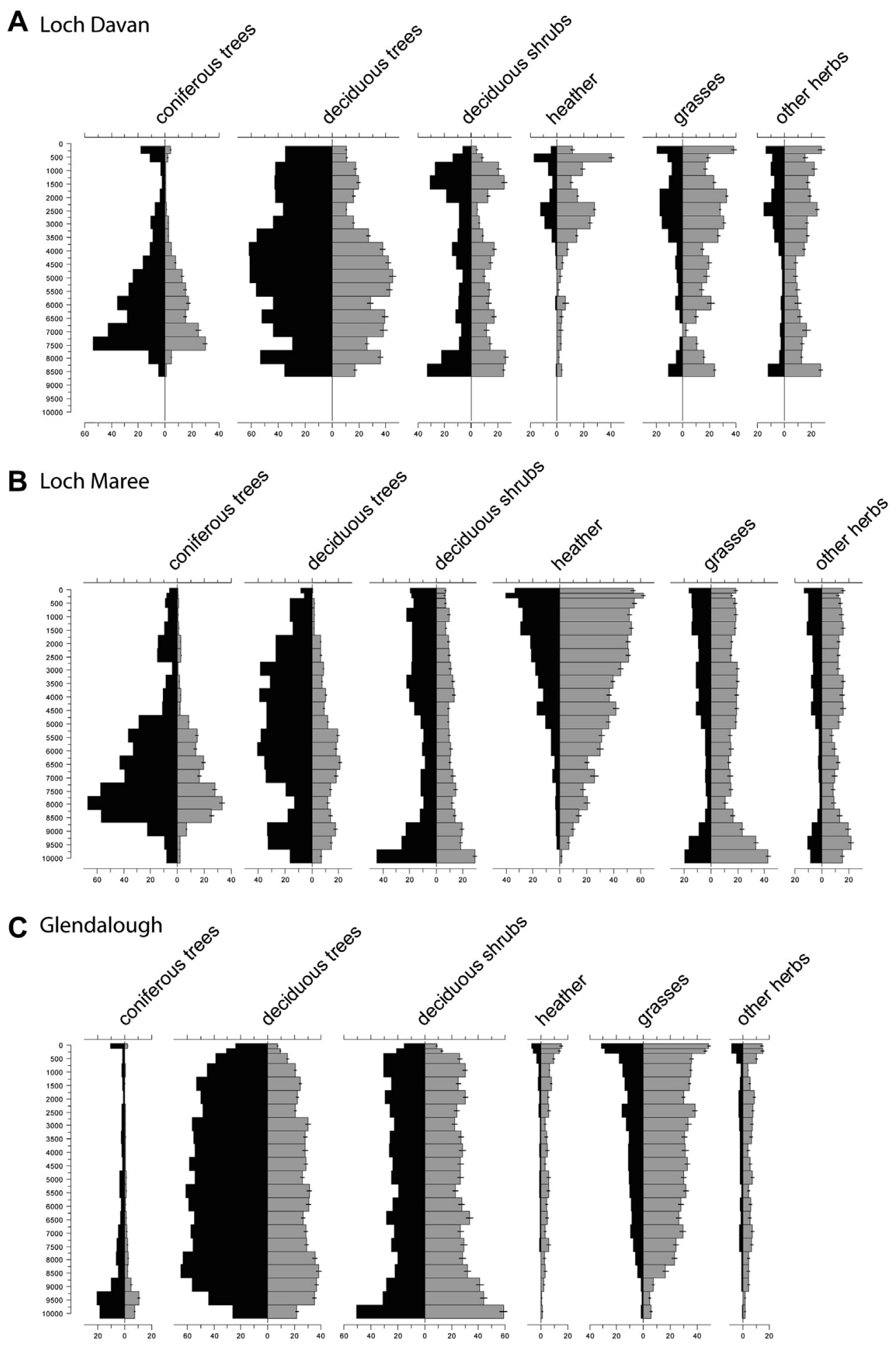

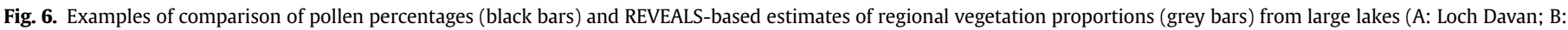
Loch Maree; C: Glendalough), showing significantly higher level of landscape/woodland openness than suggested by pollen percentage data.

The variation in regional vegetation cover may be controlled by a range of variables that show spatial patterning. These variables include biotic and environmental constraints (e.g. climate, soils: Skinner and Brown, 1999), and disturbance regimes (in particular human impact). The pattern of tree-spreading also provides a broad background to the vegetation composition in different regions during the early Holocene (Birks, 1989). Some key taxa did not reach their northern or western range limits until as late as 6000 BP, with patterns of spreading being individualistic.

The extent of wetlands (blanket bog, lowland fens, and raised mire complexes), constrains woodland development, although such ecosystems can support woody vegetation such as willow and alder, and many bogs record phases of pine growth during favourable conditions (e.g. Birks, 1975; Tallis and Switzur, 1983). 


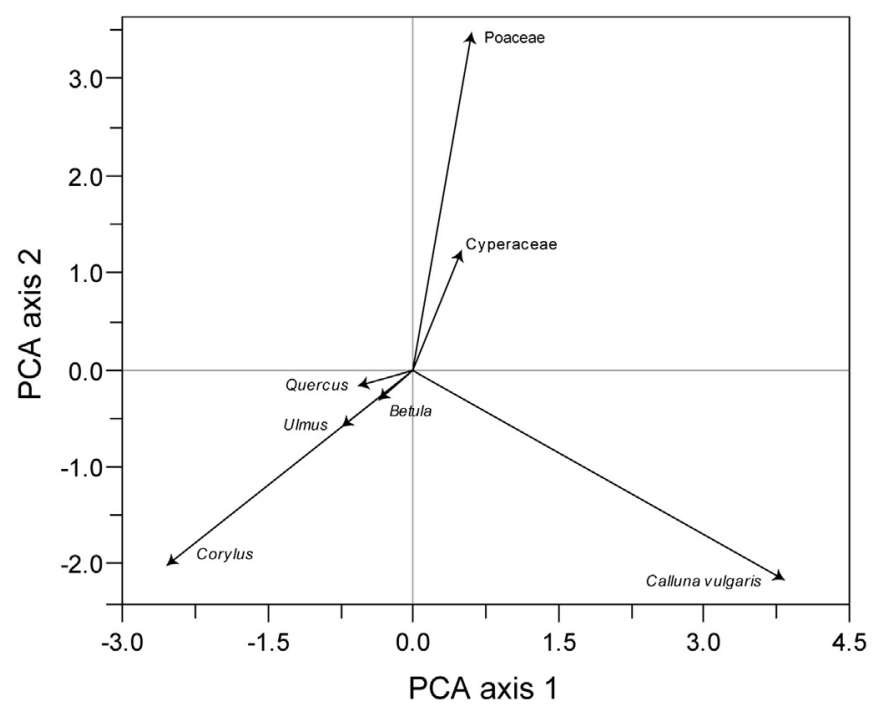

Fig. 7. Species scores from PCA of REVEALS results (PCA axis 1 eigenvalue 0.40; PCA axis 2 eigenvalue 0.26 ). For simplicity only the key taxa are shown.

These wetlands are an important landscape unit within the British Isles (Fig. 1). Northern Ireland has 25 percent peat cover, 23 percent of Scotland is covered by blanket bog, and 6 percent of England is classified as deep peat (JNCC, 2011). The current extent of peat in the Republic of Ireland is 13.8 percent, with estimates of former peat cover around 17 percent (Connolly et al., 2007). These figures can be viewed as conservative estimates for current peatland cover, given the difficulty of mapping drained or disturbed former wetland areas. Whilst these are estimates of the current and recent extent of peat, most, if not all, wetlands had developed within the British Isles by 3000 cal BP. The national inventory values hide considerable variation in the distribution of these wetland soils, which are broadly distributed on a gradient from the north-west to south-east, with few wetland areas in the south and east. In Scotland, peat dominates the north, Highlands and Western Isles, and the distribution of wetlands in England is largely in the western uplands and low-lying basins (e.g. Somerset Levels, Fenlands). In the Republic of Ireland, blanket peat is largely to be found in the north and west with the central Irish midlands covered in large raised mire complexes. The spatial extent of these wetland areas varied through the course of the Holocene; nevertheless, the distribution of wetlands broadly maps onto regions that have higher estimates of landscape/woodland openness in the past. Estimates of landscape/woodland openness in western and northern Scotland (e.g. Loch Sionascaig and Loch Maree) are considerably higher in the earlier Holocene than in eastern Scotland (e.g. Black Loch, Loch Davan). There was considerably greater landscape/woodland openness in southwest Britain than in sampled areas of southern and eastern Britain. The cluster of sites that contribute to the estimate of regional vegetation cover in the southeast (Fig. 4) are largely coastal wetlands (Waller et al., 1999). The regional vegetation estimates thus reflect the cover of these coastal environments.

The timing of key changes varies between regional estimates, in particular the reduction in woodland cover through the Holocene. In general, a decline in woodland cover begins at c. 6000 cal BP and is seen in all sequences by 2500 cal BP. Relationships between pollen-inferred woodland clearance and human activity are widely described (e.g. Roberts, 1998; Fyfe et al., 2010; Woodbridge et al., 2013). The activities of prehistoric societies were not uniform in either space or time, and the pattern of temporal and spatial variability in woodland decline clearly points towards human agency as a major driver of regional vegetation cover. It is possible that factors such as climate may have been important forcing mechanisms for vegetation cover change, but synchronicity between regions would be expected if this were the case (cf. Giesecke et al., 2011). It has also been argued that blanket peat development was a response to a combination of anthropogenic disturbance and forest clearance (Moore, 1993), and although the causes remain contested (e.g. Tipping, 2008) spread of blanket peat through the Holocene may have contributed to the gradual increase in landscape/woodland openness in some regions.

Woodland clearance appears gradual in all areas. It is important to recognise that this is a function of both the temporal and spatial scale used within this study. Using 500-year time windows means that it is not possible to identify rates of change over time-periods shorter than this interval. Many studies, however, identify substantial shifts in pollen sequences that can be rapid (e.g. Peglar, 1993; Seppä et al., 2007) and would be overlooked when sequences are re-sampled at a coarser temporal resolution. Spatial aggregation of pollen records also means that local-scale variability is overlooked. Different methods of aggregation (i.e. selections of sites within groups) may result in the zonation effect, a part of the Modifiable Areal Unit Problem widely recognised within landscape ecology (Jelinski and Wu, 1996). The zonation effect implies that different groups (zones) of pollen sequences will return different estimates of regional vegetation. In spite of this, the spatial aggregation of sites such as used here, or in Sugita et al. (2010), underpins the use of groups of sites. We seek broader (regional) patterns through aggregation. The scale at which this is done is critical as it has a direct impact on the results.

\subsection{Limitations of the work}

An important caveat to the results presented here is that the transformation of pollen proportions to estimates of vegetation proportions is model-based. These models have a range of assumptions (see Sugita, 2007a, b) meaning that uncertainties exist as to the accuracy of the transformation. These assumptions include the dispersal and deposition mechanisms of pollen grains, and in particular that the dominant taphonomic process is above-canopy component (sensu Tauber, 1967). As discussed in Section 2, a key assumption is that we can adequately describe the relationship between pollen and vegetation cover of individual pollen taxa (the pollen productivity estimate) and that this is constant in space and time. It is probable that there is a complex relationship between pollen productivity and factors that affect flowering (e.g. proximity to range limits, variation in species that comprise an individual pollen taxon, and changes in climate or land management practice), which means that PPEs may in practice vary temporally (Broström et al., 2008). Short-term ( $<5$ year) and annual variability in pollen production will be smoothed within most palaeoecological samples that span multiple years; longer-term trends are more likely to affect PPEs. Until such relationships are further explored, the estimates within the literature remain the most appropriate. Comparisons between modelled and empirical modern vegetation cover demonstrate good agreement, in spite of the assumptions and possible errors that are inherent within the approach (Hellman et al., 2008b). It is in practice impossible to validate (sensu stricto) the results of the REVEALS model for past time slices as it is impossible to generate comparable empirical vegetation datasets, but comparisons of modelled vegetation and historical maps also provides reasonable agreement (Nielsen and Odgaard, 2010).

The smoothed nature of the vegetation reconstructions has already been discussed (Section 7.2). Re-sampling of the original datasets is necessary for aggregation of sites for REVEALS analysis, generation of high pollen counts, comparison between regions, and time-equivalence for the application of the LOVE model (step 2 of 

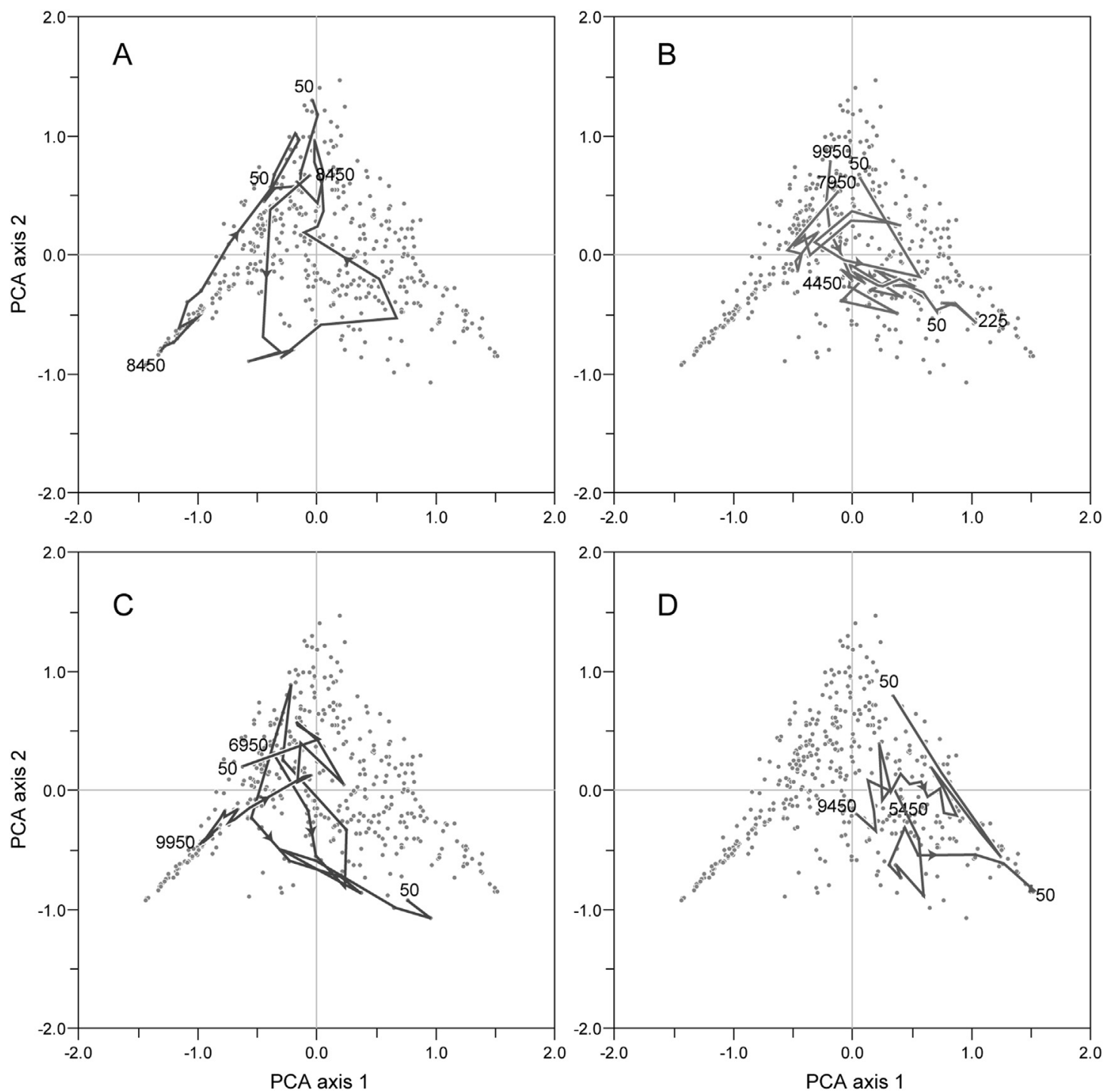

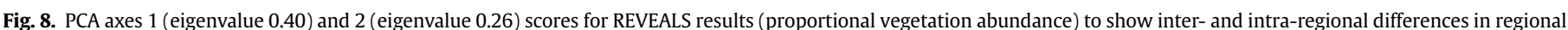

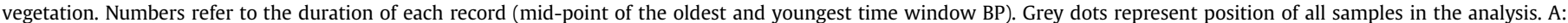
eastern mainland Scotland; B: western mainland Scotland; C: southwestern Scottish islands; D: northwestern Scottish islands.

the LRA). This means that temporal detail is lost, and age-depth models must have a reasonable degree of certainty for the allocation of samples to time windows. Where time slices are longer (e.g. 500 years) and the time interval between original samples is short (e.g. 25-50 years), then uncertainties in age-depth models become less important as each sample contributes a small fraction of the total sum for each time window (Mazier et al., 2012). When time windows are shorter, and sampling intervals longer, uncertainties in age-depth models will become more important. Nielsen and Odgaard (2010) dealt with the loss of temporal detail by using 500-year time windows for REVEALS analysis, and maintaining the original sampling ages for the target sites in the LOVE model. Changes in local vegetation estimates between target samples may therefore be an artefact of changes in the estimate of regional vegetation between the 500 year time windows, although it is hard to recognise this in their analysis.

There is considerable spatial bias within the dataset assembled and presented here, and many reconstructions are from regions which have included significant areas of peat. There are few sites that describe vegetation cover from central and southern England. The site at Hockham Mere (Bennett, 1983) appears to have greater similarities to vegetation reconstructions from Denmark and Germany (Nielsen et al., 2012) and southern Sweden (Gaillard et al., 2010) than the rest of Britain. More data from the central and southern region of England is needed to assess the degree of difference from the European mainland. The results presented here should therefore be considered the first attempt to quantify vegetation cover for the British Isles, and will only improve with the addition of further datasets.

\section{Conclusions}

Testing of the smaller groups of sites, against a single large lake, has been shown to be an appropriate method for generating a regional arboreal vegetation cover estimate in the absence of single large lakes. The results presented here indicate no systematic difference in local vegetation reconstruction from using a group of small sites to generate regional vegetation estimates. It is therefore possible to apply the REVEALS model in landscapes that might otherwise be considered unsuitable owing to a paucity of large sites for analysis. 
The application of REVEALS to 73 sequences from the British Isles results in much higher estimates of landscape/woodland openness, particularly in the first half of the Holocene, than has previously been recognised from pollen percentage data. A predominantly open landscape some 1000 years ago has been recognised from historic datasets (Rackham, 1986) and the results presented here indicate that the British Isles were also significantly open earlier in the Holocene, and were more open than other parts of Europe for which comparable data are available. The degree of openness may in part reflect the spatial bias of the sites used, which are largely from areas rich in extensive wetlands, or uplands. The estimates are thus probably reasonable for the landscapes from which they are derived, but may not be for other parts of the British Isles. Higher estimates of landscape/woodland openness that previously supposed have implications for land cover - climate feedback mechanisms, in particular surface albedo and sources and sinks of greenhouse gases (Gaillard et al., 2010; Kaplan et al., 2010).

Sites within the same broad landscape zone, or region, were statistically separated from sites in different broad landscape zones, using PCA. This further supports the use of the REVEALS model for the reconstruction of vegetation at broad spatial scales (the region), in spite of the imperfect nature of the input datasets. Betweenregion differences in vegetation estimates were greater than within-region estimates in Scotland. This understanding of the broad character of regional vegetation, and differences between regions, may allow greater opportunities for assessing regional differences in the archaeological record, and understanding the resource potential of landscapes for prehistoric communities. The approach presented here has the potential to applied beyond the temperate deciduous and boreal biomes. Work is in progress in tropic regions including Cameroon, where testing of the LRA is underway (Gaillard et al., 2012) and in India where studies are in progress to develop PPEs for the major tree and herb taxa of the cultural landscape (Krishnamurthy et al., in prep.).

\section{Acknowledgements}

This paper is a contribution to the LANDCLIM (LANDcoverCLIMate interactions in NW Europe during the Holocene) project and research network, supported by the Swedish (VR) and Nordic (Nordforsk) Research Councils, co-ordinated by Marie-José Gaillard. The authors are grateful to all members of the LANDCLIM network for fruitful discussions through the course of the network. Much of the data used in this paper were drawn from the European Pollen Database, and we are grateful to those authors who have contributed data for the benefit of the wider community. We would like to thank Rob Marchant and Fraser Mitchell for help accessing records from Ireland and Bas van Geel for allowing us to use data from Carbury Bog. Neil Roberts and the reviewers are thanked for providing valuable constructive criticism on an earlier draft of the manuscript.

\section{References}

Andersen, S.T., 1970. The Relative Pollen Productivity and Pollen Representation of North European Trees, and Correction Factors for Tree Pollen Spectra. Danmarks Geologiske Undersøgelse, Copenhagen.

Barnosky, C.W., 1988. A late-glacial and post-glacial pollen record from the Dingle Peninsula, County Kerry. Proceedings of the Royal Irish Academy 88B, 23-37.

Behre, K.E., 1986. Anthropogenic Indicators in Pollen Diagrams. AA Balkema, Rotterdam.

Bennett, K.D., 1983. Devensian late-glacial and Flandrian vegetational history at Hockham Mere, Norfolk, England. New Phytologist 95, 489-504.

Bennett, K.D., 1995. Post-glacial dynamics of pine (Pinus sylvestris L.) and pinewoods in Scotland. In: Alhous, J.R. (Ed.), Our Pinewood Heritage. Foresty Commission, Farnham, pp. 23-39.

Birks, H.H., 1972. Studies in the vegetational history of Scotland III. A radiocarbon dated pollen diagram from Loch Maree, Ross and Cromarty. New Phytologist 71, $731-754$.
Birks, H.H., 1975. Studies in the vegetational history of Scotland. IV. Pine stumps in Scottish blanket peats. Philosophical Transactions of the Royal Society Series B $270,181-226$.

Birks, H.J.B., 1989. Holocene isochrones maps and patterns of tree-spreading in the British Isles. Journal of Biogeography 16, 503-540.

Blaauw, M., 2010. Methods and code for 'classical' age-modelling of radiocarbon sequences. Quaternary Geochronology 5, 512-518.

Blackford, J.J., Edwards, K.J., Buckland, P.C., Dobney, K., 1996. Keith's peat Bank, Hoy: Mesolithic human impact. In: Hall, A.M. (Ed.), The Quaternary of Orkney: Field Guide. Quaternary Research Association, Cambridge, pp. 62-68.

Bradshaw, R.H.W., McGee, E., 1988. The extent and time-course of mountain blanket bog erosion in Ireland. New Phytologist 108, 219-224.

Bradshaw, R.H.W., Hannon, D.E., Lister, A.M., 2003. A long-term perspective on ungulate-vegetation interactions. Forest Ecology and Management 181, 267-280.

Broström, A., Nielsen, A.B., Gaillard, M.J., Hjelle, K.L., Mazier, F., Binney, H.A. Bunting, J., Fyfe, R., Meltsov, V., Poska, A., Räsänen, S., Soepboer, W., von Stedingk, H., Suutari, H., Sugita, S., 2008. Pollen productivity estimates of key European plant taxa for quantitative reconstruction of past vegetation: a review. Vegetation History and Archaeobotany 17, 416-478.

Broström, A., Sugita, S., Gaillard, M.J., 2004. Pollen Productivity Estimates for Reconstruction of Past Vegetation Cover in the Cultural Landscape of Southern Sweden.

Broström, A., Sugita, S., Gaillard, M.J., Pilesjo, P., 2005. Estimating the spatial scale of pollen dispersal in the cultural landscape of southern Sweden. The Holocene 15, 252-262.

Brown, A.G., Hatton, J., O'Brien, C.E., Selby, K.A., Langdon, P.G., Stuijts, I. Caseldine, C.J., 2005. Vegetation, landscape and human activity in Midland Ireland: mire and lake records from the Lough Kinale-Derragh Lough area, Central Ireland. Vegetation History and Archaeobotany 14, 81-98.

Brown, T., 1997. Clearances and clearings: deforestation in Mesolithic/Neolithic Britain. Oxford Journal of Archaeology 16, 133-146.

Bunting, M.J., Gaillard, M.J., Sugita, S., Middleton, R., Bröstrom, A., 2004. Vegetation structure and pollen source area. The Holocene 14, 651-660.

Bunting, M.J., Middleton, R., 2005. Modelling pollen dispersal and deposition using HUMPOL software, including simulating windroses and irregular lakes. Review of Palaeobotany and Palynology 134, 185-196.

Connolly, J., no date. Derived Irish Peat Map Version 2. Online:http://erc.epa.ie/ safer/resource?id=4b9efdbe-7f4e-102d-b891-8d8f2407b579 (accessed 13.07.12.)

Connolly, J., Holden, N.M., Ward, S.M., 2007. Mapping peatlands in Ireland using a rule-based methodology and digital data. Soil Science Society of America Journal 71, 492-499.

Cowell, R.W., Innes, J.B., 1994. The Wetlands of Merseyside. Lancaster University Press, Lancaster.

Cui, Q.-Y., Gaillard, M.J., Lemdahl, G., Greisman, A., Jacobson, G., Olsson, F., 2013. The role of tree composition in Holocene forest-fire history at two sites of the hemiboreal zone of southern Sweden, highlighted by the application of the Landscape Reconstruction Algorithm (LRA). The Holocene.

Cummings, V., Whittle, A., 2003. Tombs with a view: landscape, monuments and trees. Antiquity 77, 255-266.

Dark, P., 2006. Climate deterioration and land-use change in the first millennium BC: perspectives from the British palynological record. Journal of Archaeological Science 33, 1381-1395.

Davies, A.L., Tipping, R., 2004. Sensing small-scale human activity in the palaeoecological record: fine spatial resolution pollen analyses from Glen Affric, northern Scotland. The Holocene 14, 233-245.

Davis, M.B., 1963. On the theory of pollen analysis. American Journal of Science 261 897-912.

Davis, M.B., Calcote, R.R., Sugita, S., Takahara, H., 1998. Invasion by hemlock and the origin of the hemlock-hardwood forest mosaic. Ecology 79, 2641-2659.

Dickson, J.H., Stewart, D.A., Thompson, R., Turner, G., Baxter, M.S., Drndarsky, N.D., Rose, J., 1978. Palynology, palaeomagnetism and radiometric dating of Flandrian marine and freshwater sediments of Loch Lomond. Nature 274, 538-553.

Dodson, J.R., 1990. The Holocene vegetation of a prehistorically inhabited valley, Dingle peninsula, Co. Kerry. Proceedings of the Royal Irish Academy 90B, 151-174.

Edwards, K.J., 1978. Palaeoenvironmental and Archaeological Investigations in the Howe of Cromar, Grampian Region, Scotland. University of Aberdeen, UK. Ph.D. thesis.

Edwards, K.J., 1996. A Mesolithic of the Western and Northern Isles of Scotland? Evidence from pollen and charcoal. In: Pollard, T., Morrison, A. (Eds.), The Early Prehistory of Scotland. Edinburgh University Press, Edinburgh, pp. 23-38.

Edwards, K.J., Berridge, J.M.A., 1994. The Late-Quaternary vegetational history of Loch a'Bhogaidh, Rinns of Islay S.S.S.I., Scotland. New Phytologist 128, 749-769.

Edwards, K.J., Whittington, G., Hirons, K.R., 1995. The relationship between fire and long-term wet heath development in South Uist, Outer Hebrides, Scotland. In Thompson, D.B.A., Hestor, A.J., Usher, M.B. (Eds.), Heaths and Moorlands: Cultural Landscapes. HMSO, Edinburgh, pp. 240-248.

Edwards, K.J., Whittington, G., 1997. A 12,000-year record of environmental change in the Lomond Hills, Fife, Scotland: vegetational and climatic variability. Vegetation History and Archaeobotany 6, 133-152.

Evans, J., 2003. Environmental Archaeology and the Social Order. Routledge, London.

Farrell, M., 2009. The Environmental Context of Later Prehistoric Activity in Orkney, Scotland. Hull University, UK. Ph.D. thesis. 
Farrell, M., Bunting, M.J., Lee, D.H.J., Thomas, A., 2013. Neolithic settlement at the woodland's edge: palynological data and timber architecture in Orkney, Scotland. Journal of Archaeological Science (in press) http://dx.doi.org/10.1016/j.jas. 2012.05.042.

Fredh, D., 2012. The Impact of Past Land-use Change on Floristic Diversity in Southern Sweden: a Quantitative Approach Based on High-resolution Pollen Data. Department of Geology, Lund University. LUNDQUA thesis 66.

Fyfe, R., Caseldine, C., Gillings, M., 2010. Pushing the boundaries of data? Issues in the construction of rich visual past landscapes. Quaternary International 220, 153-159.

Fyfe, R.M., 2006. GIS and the application of a model of pollen deposition and dispersal: a new approach to testing landscape hypotheses using the POLLANDCAL models. Journal of Archaeological Science 33, 483-493.

Fyfe, R.M., 2007. The importance of local-scale openness within regions dominated by closed woodland. Journal of Quaternary Science 22, 571-578.

Fyfe, R.M., 2012. Bronze Age landscape dynamics: spatially detailed pollen analysis from a ceremonial complex. Journal of Archaeological Science 39, 2764-2773.

Fyfe, R.M., Brown, A.G., Rippon, S.J., 2003. Mid- to late-Holocene vegetation history of Greater Exmoor, UK: estimating the spatial extent of human-induced vegetation change. Vegetation History and Archaeobotany 12, 215-232.

Fyfe, R.M., Brown, A.G., Rippon, S.J., 2004. Characterising the late prehistoric, "Romano-British" and medieval landscape, and dating the emergence of a regionally distinct agricultural system in South West Britain. Journal of Archaeological Science 31, 1699-1714.

Fyfe, R.M., Brück, J., Johnston, R., Lewis, H., Roland, T., Wickstead, H., 2008. Historical context and chronology of Bronze Age enclosure on Dartmoor, UK. Journal of Archaeological Science 35, 2250-2261.

Fyfe, R.M., de Beaulieu, J.L., Binney, H., Bradshaw, R.H.W., Brewer, S., le Flao, A. Finsinger, W., Gaillard, M.J., Giesecke, T., Gil-Romera, G., Grimm, E.C., Huntley, B., Kuneŝ, P., Kuhl, N., Leydet, M., Lotter, A.F., Tarasov, P.E., Tonkov, S., 2009. The European Pollen Database: past efforts and current activities. Vegetation History and Archaeobotany $18,417-424$

Fyfe, R.M., Woodbridge, J., 2012. Differences in time and space in upland vegetation patterning: analysis of pollen data from Dartmoor, UK. Landscape Ecology 27, $745-760$.

Gaillard, M.J., Birks, H.J.B., Emaneulsson, U., Karlsson, S., Lageras, P., Olausson, D. 1994. Application of modern pollen/landuse relationships to the interpretation of pollen diagrams - reconstructions of land use history in south Sweden, 3000-0 BP. Review of Palaeobotany and Palynology 82, 47-73.

Gaillard, M.J., Lebamba, J., Sugita, S., Hély, C., Vincens, A., Mazier, F., Lézine, A.M. 2012. Application of the Landscape Reconstruction Algorithm on Holocene pollen records in Cameroon. In: Proceedings of the Colloquium Holocene Climate Change, Human Impact and Biodiversity in Western Africa, Paris.

Gaillard, M.J., Sugita, S., Bunting, M.J., Middleton, R., Bröstrom, A., Caseldine, C., Giesecke, T., Hellman, S.E.V., Hicks, S., Hjelle, H., Langdon, C., Nielsen, A.B. Poska, A., von Stedingk, H., Veski, S., POLLANDCAL members, 2008. The use of modelling and simulation approach in reconstructing past landscapes from fossil pollen data: a review and results from the POLLANDCAL network. Vegetation History and Archaeobotany 17, 419-443.

Gaillard, M.J., Sugita, S., Mazier, F., Trondman, A.K., Broström, A., Hickler, T., Kaplan, J.O., Kjellström, E., Kuneš, P., Lemmen, C., Olofsson, J., Smith, B., Strandberg, G., Fyfe, R., Nielsen, A.B., Alenius, T., Balakauskas, L., Barnekow, L., Birks, H.J.B., Bjune, A., Björkman, L., Giesecke, T., Hjelle, K., Kalnina, L., Kangur, M., van der Knaap, W.O., Koff, T., Lagerås, P., Latalowa, M., Leydet, M., Lechterbeck, J., Lindbladh, M., Odgaard, B., Peglar, S., Segerström, U., von Stedingk, H., Seppä, H., 2010. Holocene land cover reconstructions for studies on land cover-climate feedbacks. Climate of the Past 6, 483-499.

Giesecke, T., Bennett, K.D., Birks, H.J.B., Bjune, A.E., Bozilova, E., Feurdean, A Finsinger, W., Froyd, C., Pokorný, P., Rösch, M., Seppä, H., Tonkov, S., Valsecchi, V., Wolters, S., 2011. The pace of Holocene vegetation change - testing for synchronous developments. Quaternary Science Reviews 30, 2805-2814.

Godwin, H., 1975. A History of the British Flora. Cambridge University Press, Cambridge.

Goldewijk, K.K., Beusen, A., Janssen, P., 2010. Long-term dynamic modeling of global population and built-up area in a spatially-explicit way: HYDE 3.1. The Holocene 20, 565-573.

Grant, M.J., Barber, K.E., Hughes, P.D.M., 2009a. True ancient woodland? 10,000 years of continuous woodland cover at Mark Ash Wood, New Forest. In: Briant, B., Bates, M., Hosfield, R.T., Wenban-Smith, F.F. (Eds.), The Quaternary of the Solent Basin and West Sussex Raised Beaches. Quaternary Research Association, London, pp. 215-233.

Grant, M.J., Hughes, P.D.M., Barber, K.E., 2009b. Early to mid-Holocene vegetationfire interactions and responses to climate change at Cranes Moor, New Forest In: Briant, B., Bates, M., Hosfield, R.T., Wenban-Smith, F.F. (Eds.), The Quaternary of the Solent Basin and West Sussex Raised Beaches. Quaternary Research Association, London, pp. 198-214.

Grant, M.J., Waller, M.P., Groves, J.A., 2011. The Tilia decline: vegetation change in lowland Britain during the mid and late Holocene. Quaternary Science Reviews 30, 394-408

Griesman, A., Gaillard, M., 2009. The role of climate variability and fire in early and mid Holocene fire dynamics of southern Sweden. Journal of Quaternary Science 24, 593-611.

Hannon, G.E., Bradshaw, R.H.W., Nord, J., Gustafsson, M., 2008. The Bronze Age landscape of the Bjare peninsula, southern Sweden, and its relationship to burial mounds. Journal of Archaeological Science 35, 623-632.
Hellman, S., Gaillard, M.J., Bunting, J.M., Florence Mazier, F., 2009b. Estimating the relevant source area of pollen in the past cultural landscapes of southern Sweden - a forward modelling approach. Review of Palaeobotany and Palynology $153,259-271$.

Hellman, S., Bunting, M.J., Gaillard, M.-J., 2009a. Relevant Source Area of Pollen in patchy cultural landscapes and signals of anthropogenic landscape disturbance in the pollen record: a simulation approach. Review of Palaeobotany and Palynology 153, 245-258.

Hellman, S., Gaillard, M.J., Broström, A., Sugita, S., 2008a. The REVEALS model, a new tool to estimate past regional plant abundance from pollen data in large lakes: validation in southern Sweden. Journal of Quaternary Science 23, 21-42.

Hellman, S.E.V., Gaillard, M.J., Bröstrom, A., Sugita, S., 2008b. Effects of the sampling design and selection of parameter values on pollen-based quantitative reconstructions of regional vegetation: a case study in southern Sweden using the REVEALS model. Vegetation History and Archaeobotany 17, 445-459.

Huntley, B., Birks, H.J.B., 1983. An Atlas of Past and Present Pollen Maps for Europe: 0-13000 Years Ago. Cambridge University Press, Cambridge.

Jelinski, D.E., Wu, J., 1996. The modifiable areal unit problem and implications for landscape ecology. Landscape Ecology 11, 129-140.

JNCC, 2011. Towards an Assessment of the State of UK Peatlands. JNCC Report 445. Online. http://jncc.defra.gov.uk/pdf/jncc445_web.pdf (accessed 03.07.12.).

Kaplan, J.O., Krumhardt, K.M., Ellis, E.C., Ruddiman, W.F., Lemmen, C., Klein Goldewijk, K., 2010. Holocene carbon emissions as a result of anthropogenic land cover change. The Holocene 21, 775-791.

Kaplan, J.O., Krumhardt, K.M., Zimmerman, N., 2009. The prehistoric and preindustrial deforestation of Europe. Quaternary Science Reviews 28, 3016-3034.

Kreuz, A., 2008. Closed forest or open woodland as natural vegetation in the surroundings of Linearbandkeramik settlements? Vegetation History and Archaeobotany 17, 51-64.

Kuneŝ, P., Abraham, V., Kováík, O., Kopecký, M., PALYCZ Contributors, 2009. Czech Quaternary Palynological Database (PALYCA): review and basic statistics of the data. Preselia 8, 209-238.

Lepŝ, J., Ŝmilauer, P., 2003. Multivariate Analysis of Ecological Data Using CANOCO. Cambridge University Press, Cambridge.

Lindbladh, M., Bradshaw, R., Holqvist, B.H., 2000. Pattern and process in south Swedish forests during the last 3000 years, sensed at stand and regional scales. Journal of Ecology 88, 113-128.

Lomax, T.M., 1997. Holocene Vegetation History and Human Impact in Western Lewis, Scotland. University of Birmingham, UK. Ph.D. thesis.

Long, A., Waller, M., Hughes, P., Spencer, C., 1998a. The Holocene depositional history of Romney Marsh proper. In: Eddison, J., Gardiner, M., Long, A. (Eds.) Romney Marsh: Environmental Change and Human Occupation in a Coastal Lowland. OUCA Monograph, vol. 46, pp. 45-63.

Long, A.J., Waller, M.P., Plater, A.J., 2007. Dungeness and Romney Marsh: Barrier Dynamics and Marshland Evolution. Oxbow Books, Oxford.

Long, D., Waller, M., McCarthy, P., 1998b. The vegetation history of the lower Rother valley: stratigraphy and pollen data for the Shirley Moor region. In: Eddison, J., Gardiner, M., Long, A. (Eds.), Romney Marsh: Environmental Change and Human Occupation in a Coastal Lowland. OUCA Monograph, vol. 46 , pp. 31-44.

Maguire, D.J., 1983. The Inception and Growth of Blanket Peat: a Study of Northern Dartmoor. University of Bristol, UK. Ph.D. thesis.

Mazier, F., Gaillard, M.J., Kuneš, P., Sugita, S., Trondman, A.K., Broström, A., 2012. Testing the effect of site selection and parameter setting on REVEALS-model estimates of plant abundance using the Czech Quaternary Palynological Database. Review of Palaeobotany and Palynology 187, 38-49.

McLauchlan, K.K., Elmore, A.J., Oswald, W.W., Sugita, S., 2007. Detecting open vegetation in a forested landscape: pollen and remote sensing data from New England, USA. The Holocene 17, 1233-1243.

Mitchell, F.J.G., 2005. How open were European primeval forests? Hypothesis testing using palaeoecological data. Journal of Ecology 93, 168-177.

Moore, P.D., 1993. The origin of blanket mire, revisited. In: Chambers, F.M. (Ed.), Climate Change and Human Impact on the Landscape. Chapman and Hall, London, pp. 217-224.

Mulder, Y., 1999. Aspects of Vegetation and Settlement History in the Outer Hebrides, Scotland. University of Sheffield, UK. Ph.D. thesis.

Nielsen, A.B., 2004. Modelling pollen sedimentation in Danish lakes around AD 1800 -an attempt to validate the POLLSCAPE model. Journal of Biogeography 31, $1693-1709$.

Nielsen, A.B., Giesecke, T., Theuerkauf, M., Feeser, I., Behre, K.E., Beug, H.J., Chen, S.H., Christiansen, J., Döefler, W., Endtmann, E., Jahns, S., de Klerk, P., Kuhl, N., Latalowa, M., Odgaard, B.V., Rasmussen, P., Stockhom, J.R., Voigt, R., Wiethold, J., Wolters, S., 2012. Quantitative reconstructions of changes in regional openness in north-central Europe reveal new insights into old questions. Quaternary Science Reviews 47, 131-149.

Nielsen, A.B., Odgaard, B., 2010. Quantitative landscape dynamics in Denmark through the last three millennia based on the Landscape Reconstruction Algorithm approach. Vegetation History and Archaeobotany 19, 375-387.

Overballe-Petersen, M.V., Nielsen, A.B., Bradshaw, R.H.W., 2012. Quantitative vegetation reconstruction from pollen analysis and historical inventory data around a Danish small forest hollow. Journal of Vegetation Science. http:// dx.doi.org/10.1111/jvs.12007.

Parkes, H.M., Mitchell, F.J.G., 2000. Vegetation history at Clonmacnoise, Co. Offaly. Biology and Environment Proceedings of the Royal Irish Academy 100B, 35-40. 
Parsons, R.W., Prentice, I.C., 1981. Statistical approaches to R-values and pollenvegetation relationship. Review of Palaeobotany and Palynology 32, 127-152.

Peglar, S., 1993. The mid-Holocene Ulmus decline at Diss Mere, Norfolk, UK: a yearby-year pollen stratigraphy from annual laminations. The Holocene 3,1-13.

Pennington, W., Haworth, E.Y., Bonny, A.P., Lishman, J.P., 1972. Lake sediments in northern Scotland. Philosophical Transactions of the Royal Society of London 264B, 191-294.

Prentice, I.C., 1985. Pollen representation, source area, and basin size: toward a unified theory of pollen analysis. Quaternary Research 23, 76-86.

Prentice, I.C., Guiot, J., Huntley, B., Jolly, D., Cheddadi, R., 1996. Reconstructing biomes from palaeoecological data: a general method and its application to European pollen data at 0 and $6 \mathrm{ka}$. Climate Dynamics 12, 185-194.

Prentice, I.C., Parsons, R.W., 1983. Maximum likelihood linear calibration of pollen spectra in terms of forest composition. Biometrics 39, 1051-1057.

Rackham, O., 1986. The History of the Countryside. Dent, London.

Roberts, N., 1998. The Holocene: an Environmental History. Blackwell, Oxford.

Schauffler, M., Jacobson, G.L., 2002. Persistence of coastal spruce refugia during the Holocene in northern New England, USA, detected by stand-scale pollen stratigraphies. Journal of Ecology 90, 235-250.

Seppä, H., Birks, H.J.B., Giesecke, T., Hammarlund, D., Alenius, T., Antonsson, K. Bjune, A.E., Heikkilä, M., MacDonald, G.M., Ojala, A.E.K., Telford, R.J., Veski, S., 2007. Spatial structure of the 8200 cal yr BP event in northern Europe. Climate of the Past 3, 225-236.

Skinner, C., Brown, A.G., 1999. Mid-Holocene vegetation diversity in eastern Cumbria. Journal of Biogeography 26, 45-54.

Soepboer, W., Sugita, S., Lotter, A., 2010. Regional vegetation-cover changes on the Swiss Plateau during the past two millennia: a pollen-based reconstruction using the REVEALS model. Quaternary Science Reviews 29, 272-483.

Stefanini, B.S., Mitchell, F.J.G., 2011. IPOL, the Irish Pollen Site Database. Online. www.ipol.ie (accessed 16.07.12.)

Sugden, H., 1999. High Resolution Palynological, Multiple Profile and Radiocarbon Dating Studies of Early Human Impacts and Environmental Change in the Inner Hebrides, Scotland. University of Sheffield, UK. Ph.D. thesis.

Sugita, S., 1994. Pollen representation of vegetation in Quaternary sediments: theory and method in patchy vegetation. Journal of Ecology 82, 881-897.

Sugita, S., 2007a. Theory of quantitative reconstruction of vegetation I: pollen from large lakes REVEALS regional vegetation composition. The Holocene 17, $229-241$.

Sugita, S., 2007b. Theory of quantitative reconstruction of vegetation II: all you need is LOVE. The Holocene 17, 243-257.

Sugita, S., Gaillard, M.J., Bröstrom, A., 1999. Landscape openness and pollen records: a simulation approach. The Holocene 9, 409-421.

Sugita, S., Gaillard, M.-J., Hellman, S., Broström, A., 2008. Model-based reconstruction of vegetation and landscape using fossil pollen. In: Layers of
Perception, Kolloquien zur Vor- und Frühgeschichte, vol. 10, pp. 385-391. Bonn, Germany.

Sugita, S., Parshall, T., Calcote, R., Walker, K., 2010. Testing the landscape reconstruction algorithm for spatially explicit reconstruction of vegetation in northern Michigan and Wisconsin. Quaternary Research 74, 289-300.

Tallis, J.H., Switzur, V.R., 1983. Forest and moorland in the south Pennine uplands in the mid-Flandrian period. I. Macrofossil evidence of the former forest cover. Journal of Ecology 71, 585-600.

Tauber, H., 1967. Investigations of the mode of pollen transfer in forested areas. Review of Palaeobotany and Palynology 3, 277-286.

ter Braak, C.J.F., 1987. CANOCO - a FORTRAN Program for Canonical Community Ordination by [Partial] [Detrended] [Canonical] Correspondence Analysis, Principle Components Analysis and Redundancy Analysis. Agricultural Mathematics Group, Wageningen.

Tipping, R., 1994. The form and fate of Scotland's woodlands. Proceedings of the Society of Antiquaries of Scotland 124, 1-54.

Tipping, R., 2008. Blanket peat in the Scottish highlands: timing, cause, spread and the myth of environmental determinism. Biodiversity and Conservation 17, 2097-2113.

van Geel, B., Middeldorp, A.A., 1988. Vegetational history of Carbury bog (Co. Kildare, Ireland) during the last 850 years and a test of the temperature indicator value of $2 \mathrm{H} / 1 \mathrm{H}$ measurements of peat samples in relation to historical sources and meteorological data. New Phytologist 109, 377-392.

Vera, F.W.M., 2000. Grazing Ecology and Forest History. CAB International, Oxford.

Waller, M.P., 1993. Flandrian vegetational history of south-eastern England. Pollen data from Panel Bridge, East Sussex. New Phytologist 124, 345-369.

Waller, M.P., Alderton, A., Shennan, I., 1994. The Fenland Project, Number 9. Flandrian environmental change in Fenland. East Anglian Archaeology Monograph 70.

Waller, M.P., Long, A.J., Long, D., Innes, J.B., 1999. Patterns and processes in the development of coastal mire vegetation: multi-site investigations from Walland Marsh, southeast England. Quaternary Science Reviews 18, 1419-1444.

Waller, M.P., Schofield, J.E., 2007. Mid to late Holocene vegetation and landuse history in the Weald of southeast England: multiple pollen profiles from the Rye area. Vegetation History and Archaeobotany 16, 367-384.

Wells, C.E., Huckerby, E., Hall, V., 1997. Mid- and late-Holocene vegetation history and tephra studies at Fenton Cottage, Lancashire, UK. Vegetation History and Archaeobotany 6, 153-166.

Whittington, G., Edwards, K.J., Cundill, P.R., 1991. Late- and post-glacial vegetationa change at Black Loch, Fife, eastern Scotland - a multiple core approach. New Phytologist 118, 147-166.

Woodbridge, J., Fyfe, R.M., Roberts, N., Downey, S., Edinborough, K., Shennan, S. 2013. The impact of the Neolithic agricultural transition in Britain: a comparison of pollen-based land cover and archaeological ${ }^{14} \mathrm{C}$ date-inferred population change. Journal of Archaeological Science (in press) http://dx.doi.org/10.1016/j. jas.2012.10.025 